\title{
EFFECTS OF URBAN GREEN BELTS ON THE AIR TEMPERATURE, HUMIDITY AND AIR QUALITY
}

\author{
Chunyang ZHU', Peng JI', Shuhua $\mathrm{LI}^{\mathrm{c}}$ \\ ${ }^{a}$ Huazhong Agricultural University, No. 1, Shizishan Street, Hongshan District, \\ 430070 Wuhan Hubei Province, China \\ ${ }^{b}$ Heilongjiang Bayi Agricultural University, No. 5, Xinfeng Road, Longfeng District, \\ 163319 Daqing Heilongjiang Province, China \\ 'School of Architecture, Tsinghua University, Haidian District, 100084 Beijing, China
}

Submitted 16 Jul. 2015; accepted 23 May 2016

\begin{abstract}
As urbanization increases, designing green space that offers ecological benefits is an increasingly important goal of urban planning. As a linear green space in an urban environment, green belts lower air temperature, increase relative humidity, and improve air quality. To quantify the ecological effects of urban green belts and to identify a critical width for effective urban green belts, we analysed the width of urban green belts in terms of their effects on air temperature $(\mathrm{T})$, relative humidity $(\mathrm{RH})$, concentration of negative air ions (NAI) and bacteria rate (BR). The air T, RH and NAI from 8:00 to 18:00 and BR at 9:00 over seven days were investigated on six widths of green belts $(0-10 \mathrm{~m}$, 10-20 m, 20-30 m, 30-40 m, 40-50 m and over 50 m) along the west Fourth Ring Road of Beijing in April, July, October and December 2009. We found that (1) the T-RH benefits increased with the width of the green belts, and the $6 \mathrm{~m}$ belt had the smallest effect on T-RH, followed by the $16 \mathrm{~m}$ and $27 \mathrm{~m}$ belts, whereas the effect was obvious with the $34 \mathrm{~m}$ belt and conspicuous and stable with the $42 \mathrm{~m}$ belt (approximately $80 \%$ green coverage) $(P<0.05)$; $(2)$ the critical width reference value of urban green belts for an obvious effect on the increase in NAI concentration was approximately $42 \mathrm{~m}$ (approximately $80 \%$ green coverage) $(P<0.05)$ and the NAI concentration increased with the width of green belts even in July; and (3) the positive effect on the decrease in the BR was greater than the negative effect, the BR decreased with the green belt width and the changes in the BRs were stable with the $34 \mathrm{~m}$ belt. The results of this study may help urban planners and designers achieve urban green space designs that optimize ecological effects and cultural benefits.
\end{abstract}

Keywords: green belt, width, temperature-humidity (T-RH), negative air ions (NAI) concentration, bacteria rate (BR), ecological environment benefit.

\section{Introduction}

Rapid urbanization is accompanied by high concentrations of urban populations and built-up areas in many countries, creating a need to plan green space for greater ecological effectiveness (Fitzsimons et al. 2012; Smith 1993). As a linear green space in an urban environment, green belts are appropriate for various types of urban areas, and they contribute significantly to urban green space in terms of size, function, and location (Rohling 1998; Schiller 1997; Wu et al. 2012). Green belts can function as an urban ecological corridor, introducing natural airflow into inner urban areas from the suburbs to help counter the urban heat island effect (Gunn 2007). If green belts along rivers are sufficiently wide, they can improve the microclimate and impede the formation of large areas of heat blocks (Hathway, Sharples 2012). In addition to the vegetation, the thermal characteristics of urban green spaces are affected by factors such as the area and shape of the zone (Cao et al. 2010). With their highly marginalized characteristics, green belts decrease the urban heat island effect to a greater degree than green space that are circular, rectangular or other forms (Wang, Lin 2006). Generally, research efforts have focused on the temperature-humidity benefits of green belts in areas near rivers. The width of riverine green belts has been shown to affect the decrease in temperature and the increase in humidity in spring, summer and autumn; the effect is strongest in summer (Ji et al. 2013). In addition, significant research has focused on establishing the distribution of heatislands and the status of urban greening using Remote Sensing and Geographic Information Systems (Cao et al. 2010; Feyisa et al.

Corresponding author: Shuhua Li

E-mail: 155175563@qq.com 
2014; Mackey et al. 2012; Maimaitiyiming et al. 2014). The results have shown that an urban corridor system can have a clear influence on the thermal environment over a distance of $300 \mathrm{~m}$ (Du 2007). In addition, green belts play an important role in improving air quality (Islam et al. 2012). The concentration of negative air ions and bacteria rates are important indices for evaluating air quality (Tikhonov et al. 2004) and play an important role in improving environmental indicators, but related research has mainly focused on forest vegetation communities (Liang et al. 2014).

Quantifying the ecological effects of urban green belts is important for urban green space planning and construction. For example, understanding the exact extent to which a specific green belt design would impact urban ecological attributes and whether these attributes increase with the increasing width of the green belt could help create a tool that city planners and designers could use to manage urban ecological attributes more efficiently. In this study, we investigated the effects of green belts on temperature $(\mathrm{T})$, relative humidity $(\mathrm{RH})$, and the concentration of negative air ions (NAI) and bacteria (BR) using individual measurements.

The aims of the study are as follows: (1) to quantify the effects of urban green belts on T, RH, NAI and BR throughout the season and (2) to identify a critical width for effective urban green belts based on their ability to decrease $\mathrm{T}$, increase RH, increase NAI and decrease BR.

\section{Data and methods}

\subsection{Study site}

The experimental area is situated at a latitude of $39^{\circ} 57^{\prime}$ north and a longitude of $116^{\circ} 14^{\prime}$ east, and the experimental area has a warm, semi-humid climate; it is cold and dry in winter and hot and rainy in summer. The annual average temperature is approximately $11.8^{\circ} \mathrm{C}$. The lowest temperature is in January, with an average temperature of $-4.7^{\circ} \mathrm{C}$, and the highest temperature is in July, with an average temperature of $26.1^{\circ} \mathrm{C}$. The annual precipitation is $626 \mathrm{~mm}$; the peak is in summer with $75 \%$ of the annual precipitation in the period from June to August. The annual evaporation is approximately $1800-2000 \mathrm{~mm}$, which is greater than the precipitation.

The structure of Beijing's green space system is "ringshaped" and "wedge-shaped", and the "ring-shaped" structure has a heterogeneous distribution along the six ring roads in Beijing (Fig. 1). The study area is located in the west Fourth Ring Road, and the belt plots were located in a linear green space along the west Fourth Ring Road with a green cover of 70-90\% approximately $12 \mathrm{~km}$ from city centre (Tiananmen Square). The length of the study area was approximately $2.5 \mathrm{~km}$ (Fig. 1). All plots had similar plant communities and structure, which ensures consistent environmental conditions, and the widths varied according to the gradient. Six plots of different widths (0-10 m, 10-20 m, 20-30 m, 30-40 m, 40-50 m, and over $50 \mathrm{~m}$ ) were selected for evaluation. Each plot had 70-80\% green cover; one side was adjacent to a walkway while the other side was adjacent to the roadside. The control was also located along the west Fourth Ring Road; it was required to be bare, hard ground not affected by vegetation, and its surrounding environment was similar to that of the plots (Fig. 2). The meteorological conditions and traffic flow counts during the testing periods at the study site are given in Table 1. The meteorological data, including environmental T, RH, wind speed and pressure, were measured at five time intervals in April, July, October and December. The highest average air $\mathrm{T}$ for the five time intervals appeared in July, followed by April, October and December, while the peak value was observed at noon; the average RH was highest in July, followed by October, April and December, and the maximum and minimum values were detected in the morning and at noon, respectively; the highest average pressure was observed in December, followed by April, October and July, and the peak value was detected in the morning. In addition, the average wind speed was less than $0.4 \mathrm{~m} / \mathrm{s}$, and the ranges varied from $0.2 \mathrm{~m} / \mathrm{s}$ to $0.9 \mathrm{~m} / \mathrm{s}$ across four seasons at the testing points. There was no obvious difference of the traffic flow at the study site between seasons, and there were peaks in both the morning and evening of approximately

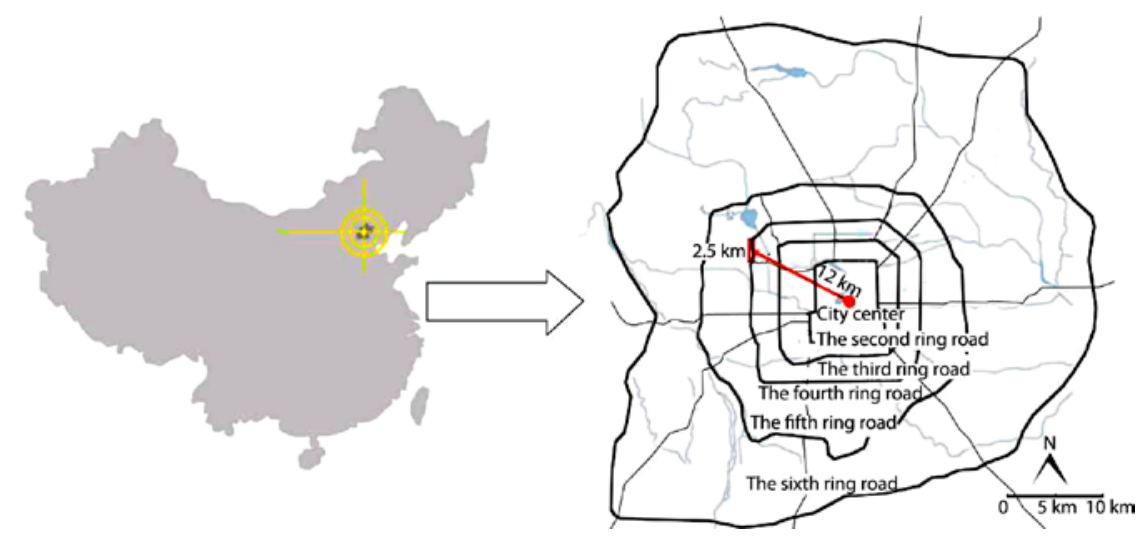

Fig. 1. Location of six green belts along the west Fourth Ring Road of Beijing 
Plans of plants distribution of the plots and the control 108000

Plot1

Plot2

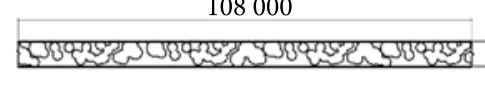

74000
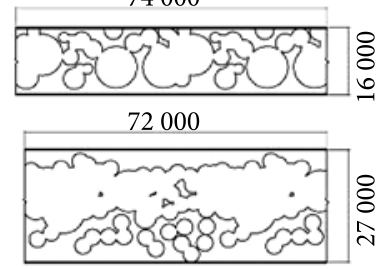

116000

Plot4

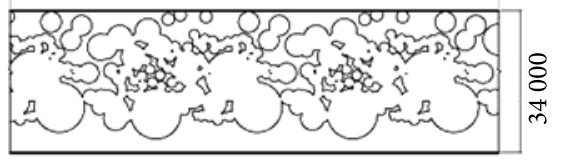

95000

Plot5

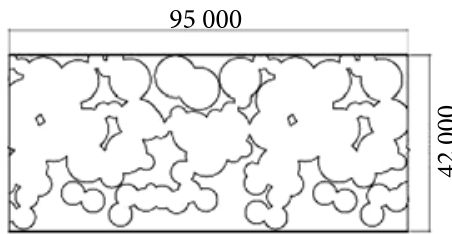

114000

Plot6

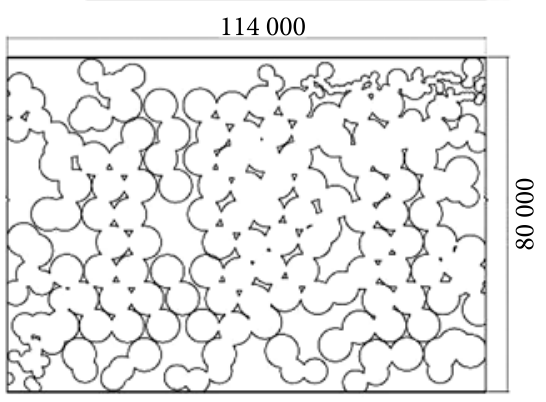

Sections of the condition around the plots and the control
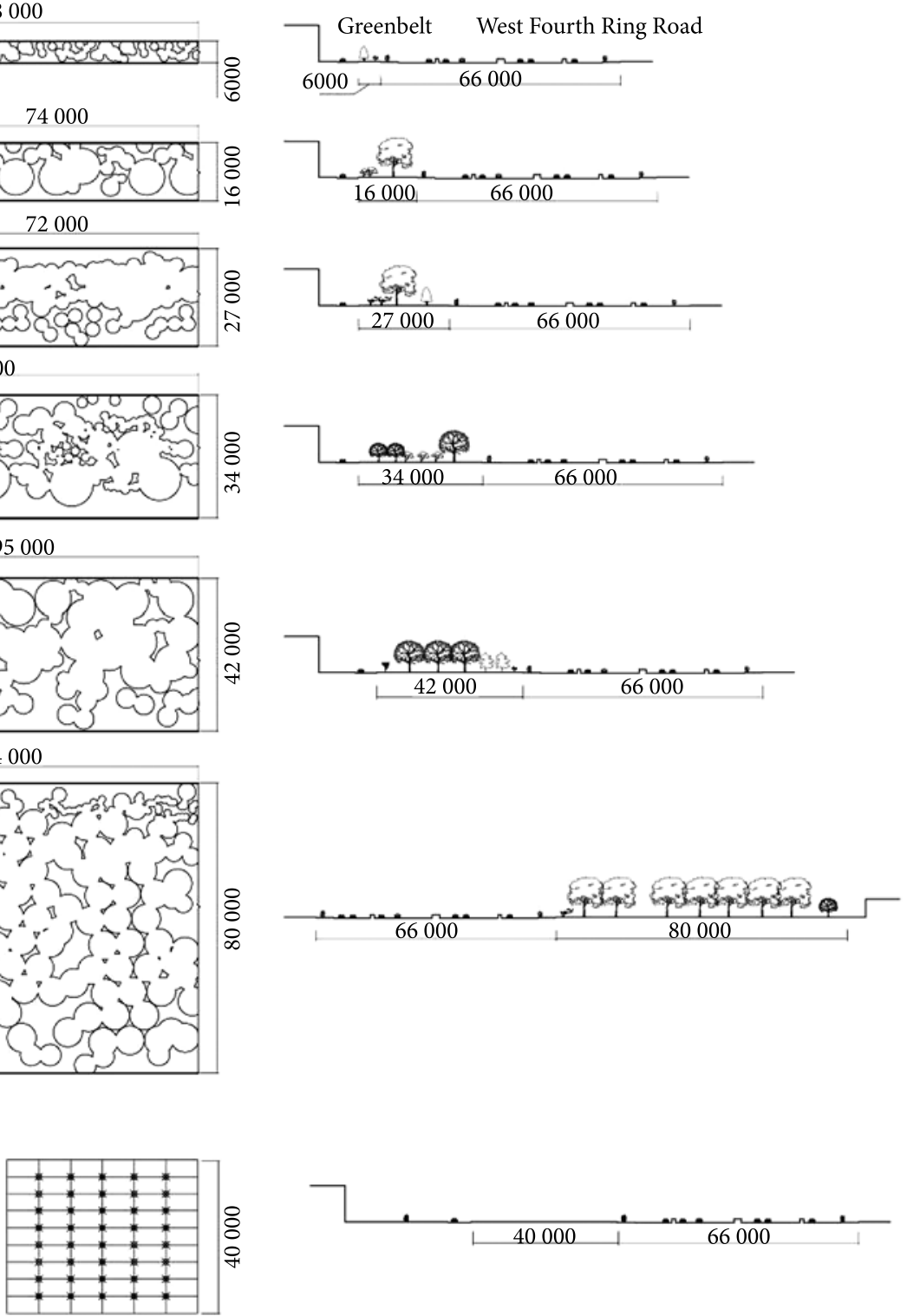

The control

Fig. 2. Diagrams of plants distribution within the green belts and sections of the areas around the green belts

Table 1. Meteorological conditions and traffic flow counts during the testing periods at the study site

\begin{tabular}{|c|c|c|c|c|c|c|c|}
\hline $\begin{array}{c}\text { Experimental } \\
\text { period }\end{array}$ & Time intervals & $\mathrm{T}\left({ }^{\circ} \mathrm{C}\right)$ & RH (\%) & $\begin{array}{c}\text { Wind speed } \\
\left(\mathrm{m} \cdot \mathrm{s}^{-1}\right)\end{array}$ & $\begin{array}{c}\text { Pressure } \\
(\mathrm{hPa})\end{array}$ & $\begin{array}{c}\text { Traffic flow } \\
\text { counts }\left(\text { Veh.h }{ }^{-1}\right)\end{array}$ & Weather \\
\hline \multirow{6}{*}{ April } & 8:00-10:00 & 16.2 & 33.4 & 0.2 & 1011.1 & \multirow{6}{*}{$14,000-19,000$} & \multirow{6}{*}{ Clear } \\
\hline & $10: 00-12: 00$ & 23.3 & 22.1 & 0.2 & 1011.3 & & \\
\hline & $12: 00-14: 00$ & 27.7 & 20.6 & 0.5 & 1009.7 & & \\
\hline & $14: 00-16: 00$ & 25.5 & 19.7 & 0.9 & 1008.2 & & \\
\hline & 16:00-18:00 & 23.6 & 22.7 & 0.2 & 1007.9 & & \\
\hline & Average & 23.3 & 23.7 & 0.4 & 1009.6 & & \\
\hline \multirow{6}{*}{ July } & 8:00-10:00 & 32.0 & 58.3 & 0.3 & 999.5 & \multirow{6}{*}{$13,000-19,000$} & \multirow{6}{*}{ Clear } \\
\hline & 10:00-12:00 & 36.0 & 37.2 & 0.2 & 999.9 & & \\
\hline & $12: 00-14: 00$ & 38.3 & 33.2 & 0.5 & 998.2 & & \\
\hline & $14: 00-16: 00$ & 39.1 & 32.7 & 0.7 & 995.8 & & \\
\hline & 16:00-18:00 & 36.6 & 43.4 & 0.2 & 995.6 & & \\
\hline & Average & 36.4 & 41.0 & 0.38 & 997.8 & & \\
\hline
\end{tabular}


End of Table 1

\begin{tabular}{|c|c|c|c|c|c|c|c|}
\hline $\begin{array}{c}\text { Experimental } \\
\text { period }\end{array}$ & Time intervals & $\mathrm{T}\left({ }^{\circ} \mathrm{C}\right)$ & RH (\%) & $\begin{array}{c}\text { Wind speed } \\
\left(\mathrm{m} \cdot \mathrm{s}^{-1}\right)\end{array}$ & $\begin{array}{c}\text { Pressure } \\
(\mathrm{hPa})\end{array}$ & $\begin{array}{c}\text { Traffic flow } \\
\text { counts }\left(\text { Veh } \cdot h^{-1}\right)\end{array}$ & Weather \\
\hline \multirow{6}{*}{ October } & $8: 00-10: 00$ & 14.6 & 46.8 & 0.4 & 1009.8 & \multirow{6}{*}{$14,000-19,000$} & \multirow{6}{*}{ Clear } \\
\hline & $10: 00-12: 00$ & 20.1 & 29.7 & 0.5 & 1010.0 & & \\
\hline & $12: 00-14: 00$ & 23.6 & 24.5 & 0.5 & 1008.4 & & \\
\hline & 14:00-16:00 & 24.2 & 23.7 & 0.4 & 1007.1 & & \\
\hline & $16: 00-18: 00$ & 21.4 & 29.6 & 0.2 & 1006.7 & & \\
\hline & Average & 20.8 & 30.9 & 0.4 & 1008.4 & & \\
\hline \multirow{6}{*}{ December } & 8:00-10:00 & -3.7 & 21.6 & 0.4 & 1024.8 & \multirow{6}{*}{$14,000-20,000$} & \multirow{6}{*}{ Clear } \\
\hline & $10: 00-12: 00$ & 2.9 & 11.2 & 0.3 & 1024.8 & & \\
\hline & $12: 00-14: 00$ & 4.2 & 9.0 & 0.3 & 1018.3 & & \\
\hline & 14:00-16:00 & 6.1 & 7.9 & 0.6 & 1020.0 & & \\
\hline & 16:00-18:00 & 0.4 & 14.0 & 0.2 & 1020.0 & & \\
\hline & Average & 2.0 & 12.7 & 0.36 & 1021.6 & & \\
\hline
\end{tabular}

20,000 Veh. $\mathrm{h}^{-1}$. There were $13,000-14,000 \mathrm{Veh} \cdot \mathrm{h}^{-1}$ at noon and 15,000-18,000 Veh.h ${ }^{-1}$ during other time intervals. Vehicle speed was less than $40 \mathrm{~km} / \mathrm{h}$ during peak traffic flow.

The basic data from the plant communities are given in Table 2.

In Table 2, the ratio of canopy density had been measured by the canopy projection method, an accurate method for the determination of small-scale vegetation. First, the trees were positioned before the horizontal distance from

Table 2. Basic characteristics of the six green belts

\begin{tabular}{|c|c|c|c|}
\hline $\begin{array}{l}\text { Green } \\
\text { belt } \\
\text { width } \\
(\mathrm{m})\end{array}$ & Plant Constitution & $\begin{array}{l}\text { Planting } \\
\text { density } \\
\text { (plants/ } \\
\mathrm{m}^{2} \text { ) }\end{array}$ & $\begin{array}{l}\text { Canopy } \\
\text { Density } \\
\quad(\%)\end{array}$ \\
\hline 6 & $\begin{array}{l}\text { Sabina chinensis, Prunus } \\
\text { triloba }\end{array}$ & 0.095 & $70-80$ \\
\hline 16 & $\begin{array}{l}\text { Sophora japonica, Sabina } \\
\text { chinensis, Lonicera maackii }\end{array}$ & 0.036 & $70-80$ \\
\hline 27 & $\begin{array}{l}\text { Sophora japonica, Sabina } \\
\text { chinensis, Prunus triloba, } \\
\text { Forsythia suspensa }\end{array}$ & 0.035 & $70-80$ \\
\hline 34 & $\begin{array}{l}\text { Salix matsudana cv. } \\
\text { Pendula, Sabina chinensis, } \\
\text { Lonicera maackii, } \\
\text { Forsythia suspensa, } \\
\text { Ligustrum } \times \text { vicaryi }\end{array}$ & 0.039 & $70-80$ \\
\hline 42 & $\begin{array}{l}\text { Salix matsudana cv. } \\
\text { Umbraculifera, Fraxinus } \\
\text { chinensis, Sophora japonica, } \\
\text { Pinus tabulaeformis, Sabina } \\
\text { chinensis, Prunus ceraifera } \\
\text { cv. Pissardii }\end{array}$ & 0.033 & $70-80$ \\
\hline 80 & $\begin{array}{l}\text { Salix matsudana cv. } \\
\text { Pendula, Robinia } \\
\text { pseudoacacia, Forsythia } \\
\text { suspensa }\end{array}$ & 0.030 & $75-85$ \\
\hline
\end{tabular}

the edge of the crown to the trunk was measured in different directions. Second, the vertical projection diagram was drawn on grid-shaped paper using the measured data, the repeated calculation of overlapping trees was eliminated, and the total areas of the crown projection were calculated. Finally, the canopy projection was calculated with the ratio of area of crown vertical projection/area of green.

\subsection{Methods}

To test $\mathrm{T}$ and $\mathrm{RH}$, mesh points were set in the plots. Each plot was divided into 4 sections with replications; each section was evenly divided into 8 test points longitudinally and 3 replications transversely. 40 points were selected as the control. T and RH were measured $1.5 \mathrm{~m}$ above the ground.

To accurately measure $\mathrm{T}$ and $\mathrm{RH}$, the $\mathrm{T}$ and $\mathrm{RH}$ probes were located in the shadow of the crown or observer to avoid the inaccurate data caused by direct solar radiation.

To test the NAI concentration, the stationing method was used with the T and RH distribution. NAI was measured at $1.5 \mathrm{~m}$ above the ground around the east, west, north and south, respectively.

In the paper, the $q$ and $C I$ were the evaluation index of the NAI concentration, as shown in the following formula:

$$
q=\frac{n^{+}}{n^{-}}
$$

where $n+$ is the positive ion rates; $n-$ is the negative ion rates; and

$$
C I=\frac{n^{-}}{1000 q} .
$$

To test the BR, the plate Medium Composed Method was used. The petri dish number was calculated after $5 \mathrm{~min}$ in the air, followed by culturing at $37^{\circ} \mathrm{C}$ for 48 hours.

The stationing method was used with the $\mathrm{T}$ and $\mathrm{RH}$ distribution, and BRs were measured $1.5 \mathrm{~m}$ above the ground. 
The BR per cubic meter was calculated by the Ormeilians formula. The formula is as follows:

$$
\mathrm{BR} / \mathrm{m}^{3}=\frac{5000 N}{A \times t},
$$

where $N, A$ and $t$ represent the BRs in plates, area of the Petri dish $\left(\mathrm{cm}^{2}\right)$, and time exposed in the air ( $\left.\mathrm{min}\right)$, respectively.

The experimental period was in April, July, October and December of 2009. The data on air T, RH and NAI concentrations as well as the meteorological conditions were calculated in sunny and windless weather from 8:00 to 18:00 every day for 3 days in six plots; measured every 2 hours and recorded for 2 minutes of each test point at 8:00, 10:00, 12:00, 14:00 and 16:00 at each time interval; and the BR was calculated at 9:00.

\subsection{Testing instrument}

$\mathrm{T}$ and $\mathrm{RH}$ were detected by a temperature and humidity recorder (FUSO 8829, Japan). The device had a measuring range of -40 to $85{ }^{\circ} \mathrm{C}$ and $0-100 \% \mathrm{RH}$ with a resolution of $0.1{ }^{\circ} \mathrm{C}$ and $0.1 \% \mathrm{RH}$. The test requirement for measurements was to stay within the plot and control for $5 \mathrm{~min}$ utes before testing to ensure a stable $\mathrm{T}$ and $\mathrm{RH}$.

The NAI concentration was analysed by an anion concentration tester (ZL1-DLY-5G, USA) that had a measuring range of $10-1.999 \times 10^{9} \mathrm{ions} / \mathrm{cm}^{3}$, a resolution of $10 \mathrm{ions} / \mathrm{cm}^{3}$, and an error $\leq \pm 10 \%$. The ion mobility was $0.15 \mathrm{~cm}^{2} / \mathrm{V} \cdot \mathrm{sec}$, the linear flow rate of air sampling was $180 \mathrm{~cm} / \mathrm{sec}$, the response time constant was approximately $15 \mathrm{sec}$, and the rated working environment had a temperature range from -0 to $40^{\circ} \mathrm{C}$ and a relative humidity $\leq 90 \%$.
The BR was tested using an agar plate medium in a petri dish. The agar plate medium consisted of peptone, glucose, and beef extract.

\subsection{Data processing}

The data were analysed using SPSS 17.0 and Eviews 7.0 software. Descriptive statistical analyses were performed to evaluate the average, variability, standard deviation and regression for each parameter measured and the autocorrelation processing for the $\mathrm{T}$ and $\mathrm{RH}$ measured. ANOVA was performed according to the 3 days replications design. The means were compared using the Duncan's multiple range test at the 0.05 level of probability.

\section{Results}

\subsection{Effects of different widths of green belts on air temperature and relative humidity}

2.1.1. Air temperature and relative humidity changes over five time intervals

The air $\mathrm{T}$ and $\mathrm{RH}$ gap for each plot was analysed compared with the control for all five time intervals respectively.

The effect on T changed gradually with time according to the comparison of the six plots over the five time intervals (Fig. 3). In July and October, the peaks were at 12:00-14:00 and 14:00-16:00. In April, the peaks were at 12:00-14:00 and 16:00-18:00. The effects differed by season and across the five time intervals. In December, all of the green belts had increased $\mathrm{T}$ during cooler parts of the day, that is, at 8:00-10:00 and 16:00-18:00, whereas

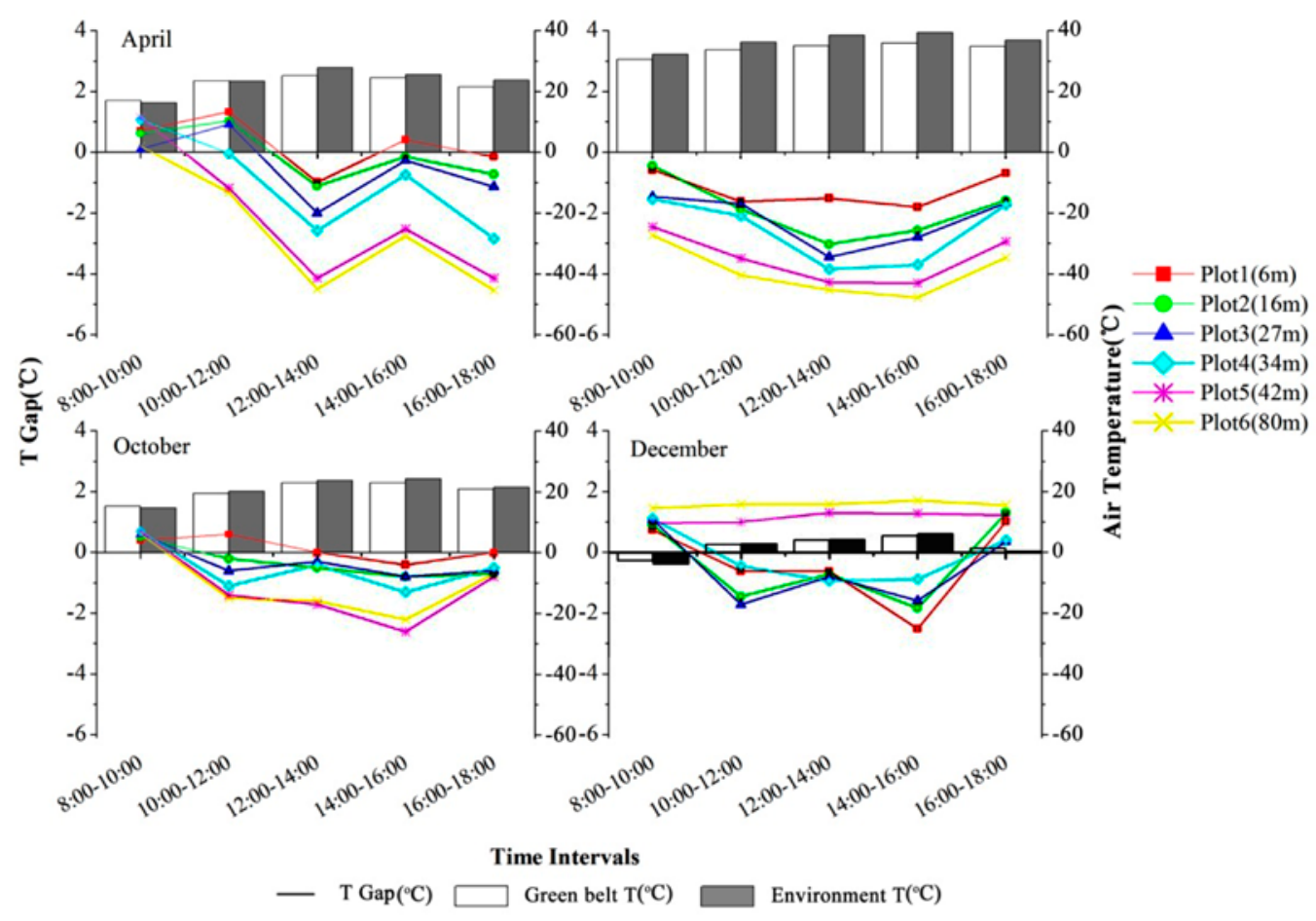

Fig. 3. T changes of green belts over five time intervals 
plots 5 and 6 showed increased $\mathrm{T}$ for all time intervals. For example, the data collected at 14:00-16:00 from July indicate the most significant environmental benefits of lower $\mathrm{T}$. The $\mathrm{T}$ in plot 1 was $1.8^{\circ} \mathrm{C}$ lower than that of the control; the $\mathrm{T}$ in plots 2 and 3 was $2.6-2.8^{\circ} \mathrm{C}$ lower; the $\mathrm{T}$ of plot 4 was $3.7^{\circ} \mathrm{C}$ lower; and the $\mathrm{T}$ of plots 5 and 6 was 4.4-4.8 ${ }^{\circ} \mathrm{C}$ lower. This result indicates that the $\mathrm{T}$ effect was stronger in wider plots. The amount of $\mathrm{T}$ reduction was smaller at 16:00-18:00, indicating that the T-lowering effect of the green belt was not very strong for the ambient temperature decrease compared with that of 14:00-16:00.

The increase in $\mathrm{RH}$ was most conspicuous in all six plots at 8:00-10:00 and 16:00-18:00 in April and at 8:00-10:00 and 10:00-12:00 in July. In October, the maximum difference was at 14:00-16:00, whereas in December, the effect was not obvious for any time interval because the vegetation had lost its leaves (Fig. 4). In July, the increase in RH in plots 4-6 was greater than in plots 1-3. The greatest increase was in plot 6 , which was $15 \%$ more humid than the control group. In plot 5, the $\mathrm{RH}$ was $4 \%$ higher than in plot 4 . The effect on the increase in $\mathrm{RH}$ was most evident in plots 5 and 6 (Fig. 4).

The results indicated that width exerted a definite effect on the decrease in $\mathrm{T}$ and increase in $\mathrm{RH}$ for all plots in April, July and October. A clear effect of width was observed in plot 4 , where green belt effects were stronger than in plots 1-3 at 12:00-14:00 and 14:00-16:00. A conspicuous, stable effect was evident in plots 5 and 6; the effect in plot 5 was as great as that in plot 6 from 10:00 to 16:00.

\subsubsection{Changing average air temperature and relative humidity over 3 days}

The 3-day average air T and RH gap for each plot was analysed compared with the control for the five time intervals.

The benefit as measured by the 3-day average $\mathrm{T}$ increased with the width of the six plots during April, July and October, and the order was plot $6>$ plot $5>$ plot $4>$ plot $3>$ plot $2>$ plot 1 (Fig. 5). The variance analysis(ANOVA) showed a significant difference in the 3-day average $\mathrm{T}$ in the six plots compared with the control group using Duncan's post hoc tests $(P<0.05)$. The T benefit of plot 1 was notable despite being the narrowest. By contrast, the green belts did not produce an obvious effect until a certain width was attained. In April and July, the differences in air $\mathrm{T}$ between plots 5 and 6 were not significant despite the greater width of plot 6 . There were no significant differences between plots 5 and 4, but there were significant differences between plot 5 and plots 1, 2, and 3. There were no significant differences among plots 1,2 , 3 and 4 . In December, there was no significant difference between plots 5 and 6 . The $\mathrm{T}$ benefit was most obvious in July, when plot 4 was $2.6{ }^{\circ} \mathrm{C}$ cooler than the control and plots 5 and 6 were $3.5^{\circ} \mathrm{C}$ and $3.9^{\circ} \mathrm{C}$ cooler, respectively. From this analysis, the critical width reference value for an urban green belt to effect an obvious decrease in $\mathrm{T}$ was approximately $34 \mathrm{~m}$ (plot 4), with an optimal width reference value of approximately $42 \mathrm{~m}$ (plot 5).

As observed from the 3-day average $\mathrm{RH}$ for all time intervals (Fig. 6), there were some influences on the increase in $\mathrm{RH}$ in all the plots (plot $6>$ plot $5>$ plot $4>$ plot $3>$ plot $2>$

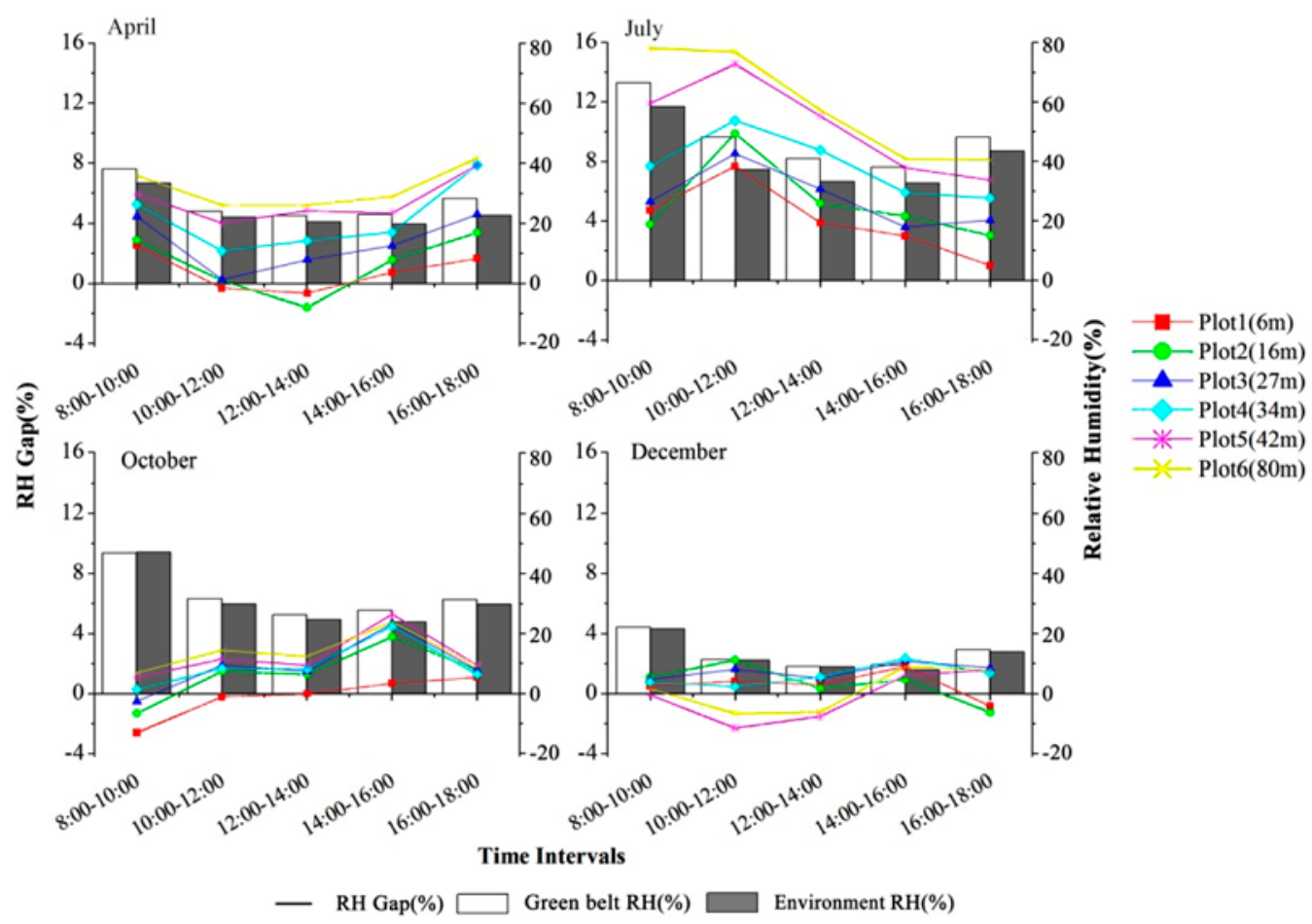

Fig. 4. RH changes of green belts over five time intervals 
plot 1) during April, July and October. The variance analysis indicated that the differences in the 3-day average $\mathrm{RH}$ among the six green belts and the control group were significant based on Duncan's post hoc tests $(P<0.05)$. There was an obvious benefit to $\mathrm{RH}$, and significant differences were detected at certain times: in April and July, there were no significant differences between plots 5 and 6 or between plots 4 and 5; however, there were significant differences between plot 5 and plots 1, 2, and 3. In October and December, there were no obvious differences among the six plots. The $\mathrm{RH}$ benefit was most obvious in July, when plot 4 was $7.6 \%$ more humid than the control, and plots 5 and 6 were $10.2-11.6 \%$ more humid than the control. According to this analysis, the critical width reference value for an urban green belt to clearly raise $\mathrm{RH}$ was approximately $34 \mathrm{~m}$ (plot 4), and the optimal width reference value was approximately $42 \mathrm{~m}$ (plot 5). The 3-day average $\mathrm{T}$ and $\mathrm{RH}$ showed that the benefits increased with the width of the green belt. In April, July and October,

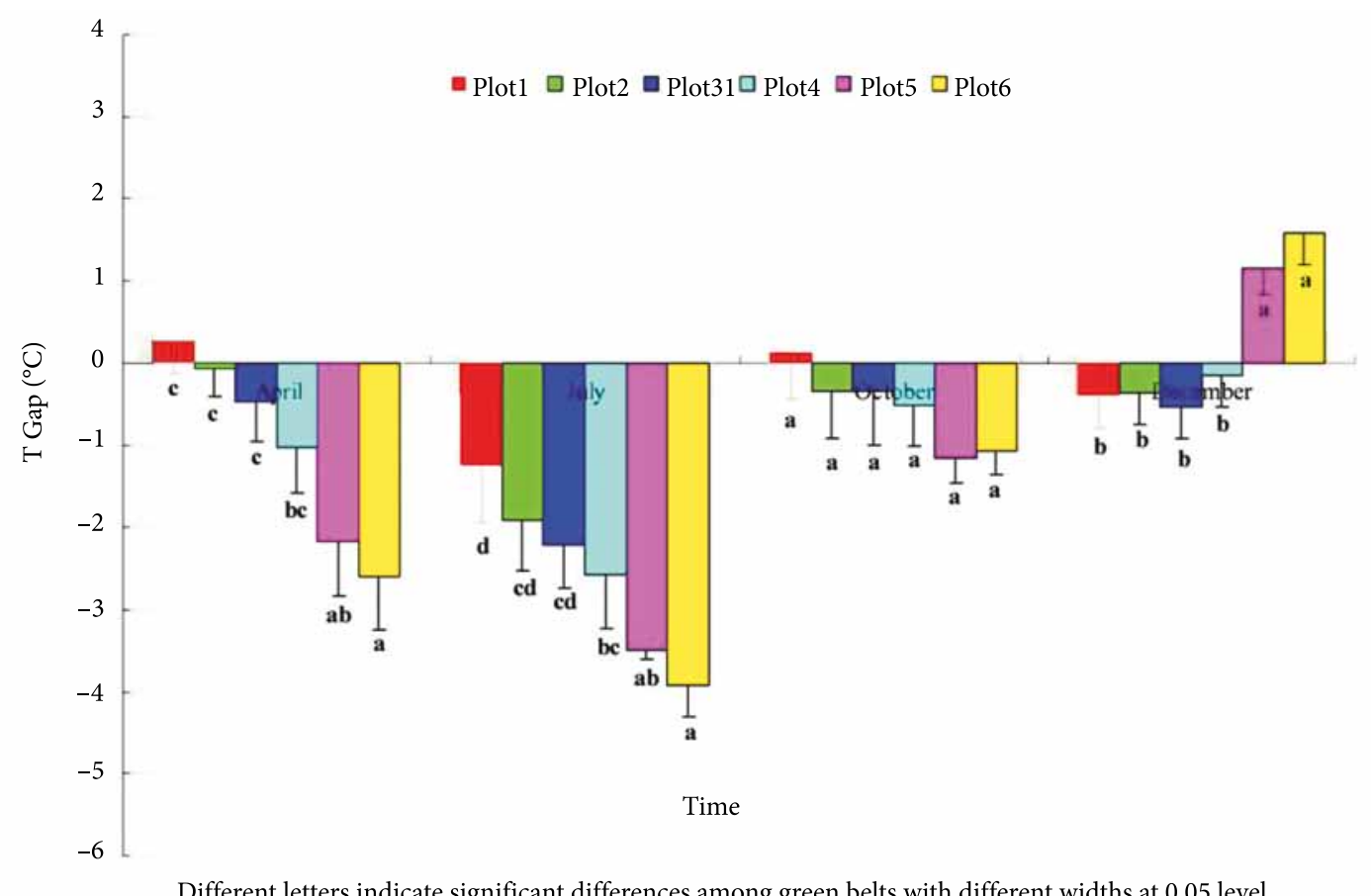

Different letters indicate significant differences among green belts with different widths at 0.05 level.

Fig. 5. The 3-day average of air $\mathrm{T}$ in the green belts

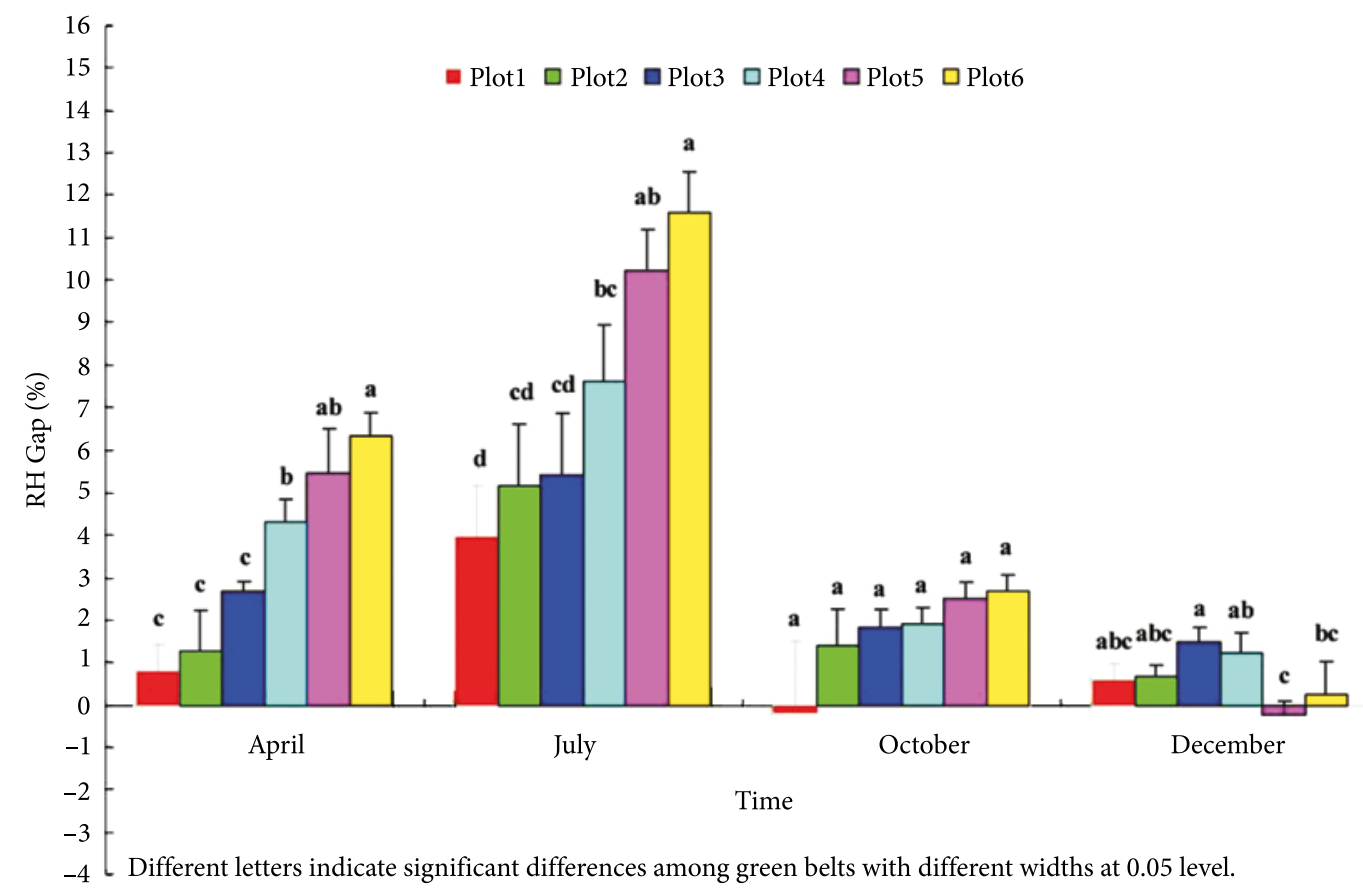

Fig. 6. The 3-day average of air $\mathrm{RH}$ in the green belts 


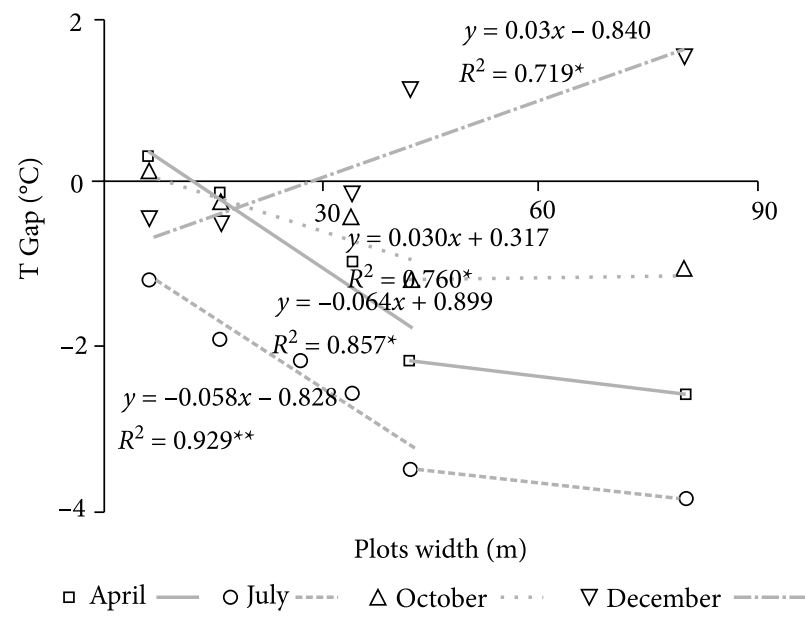

Fig. 7. Linear correlation analysis of average $\mathrm{T}$ in green belts

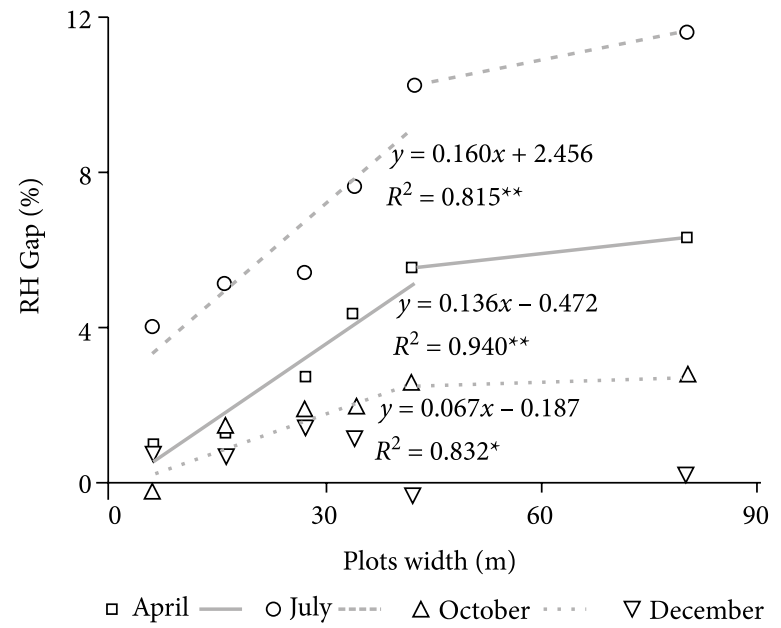

Fig. 8. Linear correlation analysis of average $\mathrm{RH}$ in green belts

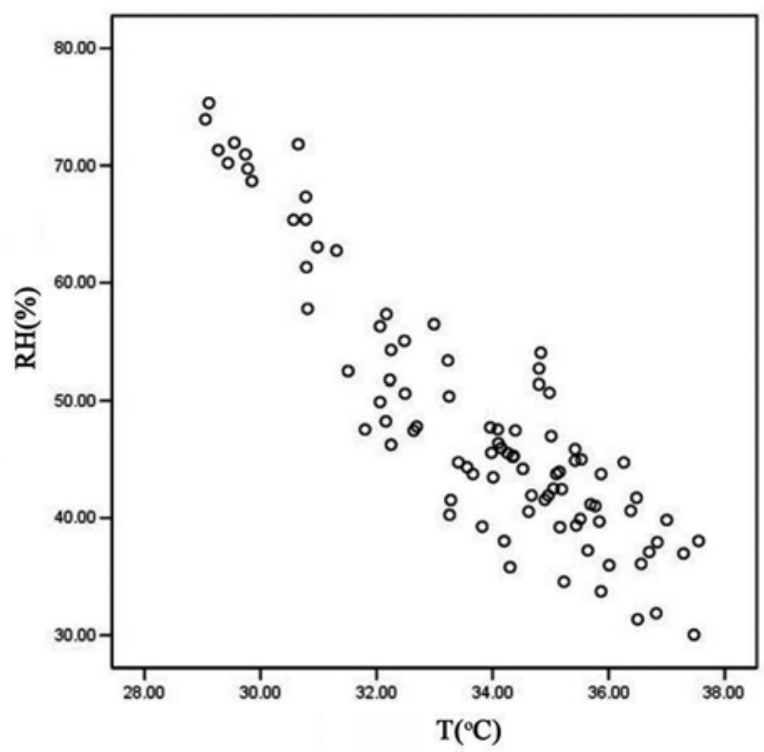

Fig. 9. Scatter diagram of the correlation trend of air $\mathrm{T}$ and $\mathrm{RH}$ the width of plot 1 had little effect on $\mathrm{T}$ and no obvious effect on $\mathrm{RH}$. A moderate effect on T-RH benefits was observed in plots 2-4, whereas a conspicuous, stable effect was observed in plots 5 and 6. In December, there was an obvious effect of the plots on the increase in $\mathrm{T}$ in the green belt, with plots 5 and 6 showing the greatest effect.

From the linear correlation analyses of the average $\mathrm{T}$ and $\mathrm{RH}$ (Fig. 7; Fig. 8), the $\mathrm{T}$ and $\mathrm{RH}$ benefits in plot 5 were similar to those in plot 6 and higher than those in plot 4 even though the width of plot 5 was not markedly different from that of plot 4 . Both, however, are distinctly different from that of plot 6 . It can be concluded that the optimal width reference value of an urban green belt for the effect on the decrease in $\mathrm{T}$ and the increase in $\mathrm{RH}$ was that of plot 5 .

\subsubsection{Regression analysis of air temperature and relative humidity}

Air temperature is related to the relative humidity in the green space. However, relationships between $\mathrm{T}$ and $\mathrm{RH}$ are different in different types of green space, especially in the green belt with a marginal characteristic (Wang, Lin 2006; Cohen et al. 2012).

A regression analysis was applied to the average $\mathrm{T}$ and RH data (90 readings) over 3 days for the six plots (bivariate) in July, when the environmental benefits were at their most significant. From the scatter diagram of the correlation trend (Fig. 9), there was a significant linear correlation between $\mathrm{T}$ and $\mathrm{RH}$. The correlation coefficient between $\mathrm{T}$ and $\mathrm{RH}$ was $-0.898^{\star \star}$ (** represents significance, $P<0.01)$ from the analysis of the correlation coefficient matrix. The Spearman rank correlation coefficient was also determined by analysing a matrix of the nonparametric correlation coefficients to be $-0.848^{\star *}(P<0.01)$.

In the regression model, $\mathrm{F}$ was determined to be $366.086(P<0.01)$, so the model was statistically significant. From an analysis of residual statistics, the results showed a normal distribution. Using the generalised difference method in Eviews, DW $=1.83$, du $<$ DW $<4$-du, there was no autocorrelation of the model when the first observed value underwent Prais-Winsten transformation. In the regression equation, $\mathrm{Y}(\mathrm{RH})=184.721-4.038 \times$ $\mathrm{X}(\mathrm{T})$ was based on the regression analysis between $\mathrm{T}$ and $\mathrm{RH}$ in the six green belts (Table 3).

\subsection{Effect of green belt width on negative air ion concentration}

2.2.1. Negative air ion concentration changes for the five time intervals

The difference in NAI concentration between each plot and the control was analysed over five time intervals.

Figure 10 shows that the maximum and minimum NAI concentrations differed among the five time intervals 
by season. The NAI concentrations in April and July were similar for the plots and control when the maximums were at 8:00-10:00 (355 and 466 ions $/ \mathrm{cm}^{3}$, respectively) and the minimums were at 12:00-14:00 (240 and $189 \mathrm{ions} / \mathrm{cm}^{3}$, respectively). In October, the maximum occurred at 12:00-14:00 (246 ions $\left./ \mathrm{cm}^{3}\right)$, and the minimum occurred at 16:00-18:00 (161 ions/ $\left.\mathrm{cm}^{3}\right)$. In December, when the

Table 3. Autocorrelation processing of the regression model of air $\mathrm{T}$ and $\mathrm{RH}$ in the six green belts

\begin{tabular}{lcccc}
\hline \multicolumn{5}{c}{ Dependent Variable: Y $-0.285{ }^{*} \mathrm{Y}(-1)$} \\
\hline \multicolumn{4}{c}{ Method: Least Squares } \\
\hline $\mathrm{C}$ & 131.9096 & 6.554161 & 20.12609 & 0.0000 \\
\hline $\mathrm{X}-0.2859{ }^{*}$ & -4.037758 & 0.270770 & -14.91213 & 0.0000 \\
$\mathrm{X}(-1)$ & $\begin{array}{c}\text { Standard } \\
\text { Error }\end{array}$ & t-Statistic & Probability \\
\hline $\begin{array}{l}\text { R-squared } \\
\text { Coefficient }\end{array}$ & 0.718785 & $\begin{array}{c}\text { Mean dependent } \\
\text { variable }\end{array}$ & 34.44522 \\
\hline $\begin{array}{l}\text { Adjusted } \\
\text { R-squared }\end{array}$ & 0.715552 & $\begin{array}{c}\text { S.D. dependent } \\
\text { variable }\end{array}$ & 8.644510 \\
\hline $\begin{array}{l}\text { Standard } \\
\text { Error of } \\
\text { regression }\end{array}$ & 4.610431 & Akaike info criterion & 5.916735 \\
\hline $\begin{array}{l}\text { Sum } \\
\text { squared } \\
\text { residue }\end{array}$ & 1849.278 & Schwarz criterion & 5.972660 \\
\hline $\begin{array}{l}\text { Log } \\
\text { likelihood }\end{array}$ & -261.2947 & F-statistic & 222.3716 \\
\hline $\begin{array}{l}\text { Durbin- } \\
\text { Watson } \\
\text { statistic }\end{array}$ & 1.830497 & Probability (F-statistic) & 0.000000 \\
\hline
\end{tabular}

leaves fell, the NAI concentration showed little variation.

The width of the green belt was an important factor in the NAI concentration. In July, the NAI concentration was the highest, and all plots had a similar trend. The NAI concentrations in plots 4-6 were higher than in plots 1-3, and plot 6 had the highest NAI concentration, with the maximum NAI concentration at 8:00-10:00 $\left(1032\right.$ ions $\left./ \mathrm{cm}^{3}\right)$ and the minimum at 12:00-14:00 $\left(220\right.$ ions $\left./ \mathrm{cm}^{3}\right)$.

\subsubsection{Changing average negative air ions concentration over 3 days}

The 3-day average NAI concentration for the five time intervals was analysed for the plots and the control.

The 3-day average NAI concentration (Fig. 11) showed that the NAI concentration benefit increased with the width of the plots during April, July and October, and the order was plot $6>$ plot $5>$ plot $4>$ plot $3>$ plot $2>$ plot 1 . The NAI concentrations in wider plots were 1.5-2.5 times higher than those of the narrower plots. Based on Duncan's post hoc tests $(P<0.05)$, in April, there was no significant difference in the 3 -day averages of NAI between plots 5 and 6 , but there were significant differences between plots 5 and 6 and other plots. In July, there was a significant difference between plot 6 and the other plots and no obvious difference between plots 4 and 5, but there was a significant difference between plots 4 and 5 and plots 1-3. In October, there was no significant difference between plot 6 and plots 4 and 5 or between plots 4 and 5 and plot 3 , but there was a significant difference between plots 6 and 3. However, there was a significant difference between plots 4 and 5 and plots 1 and 2. In December,

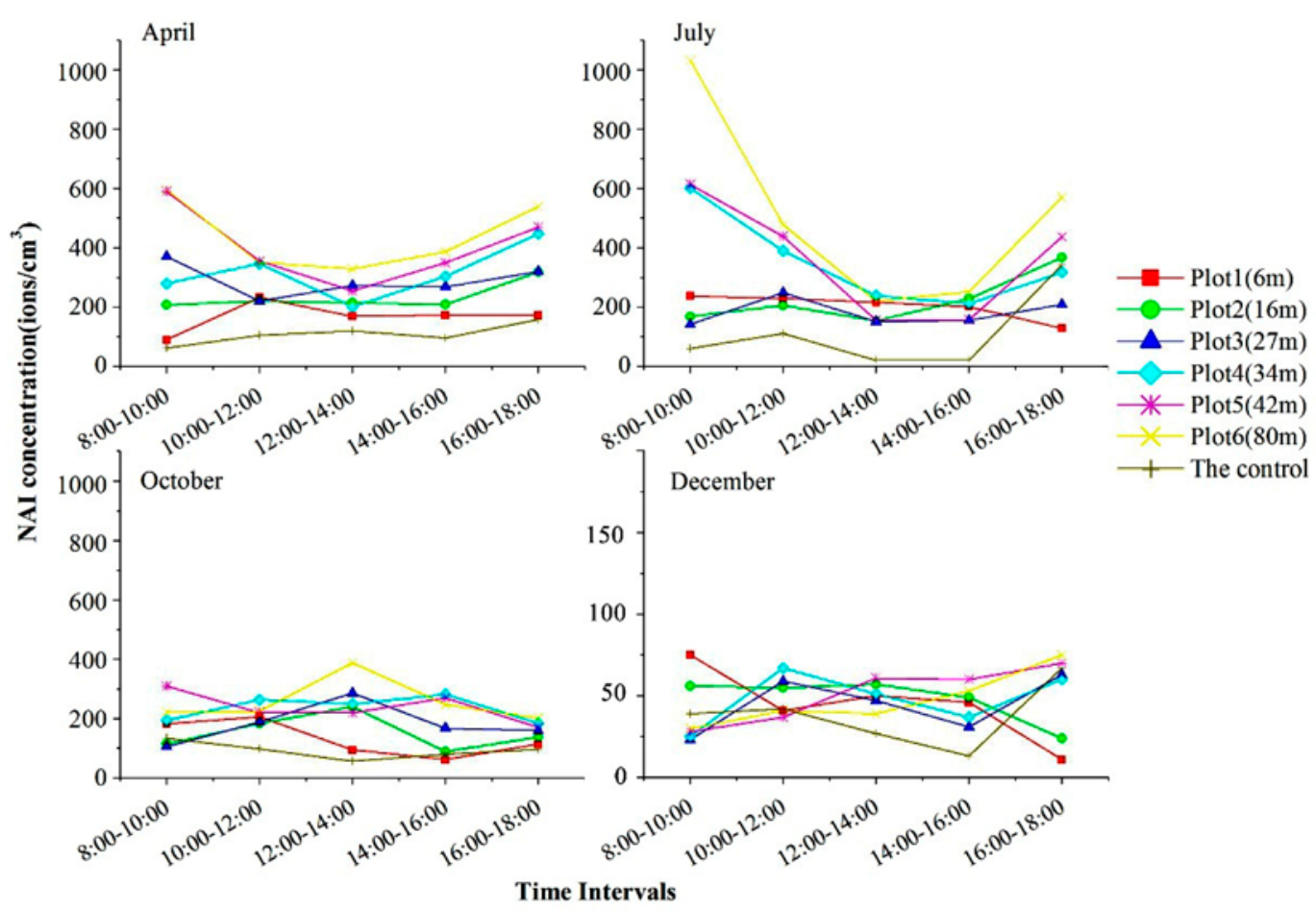

Fig. 10. NAI concentration changes of the green belts over five time intervals 


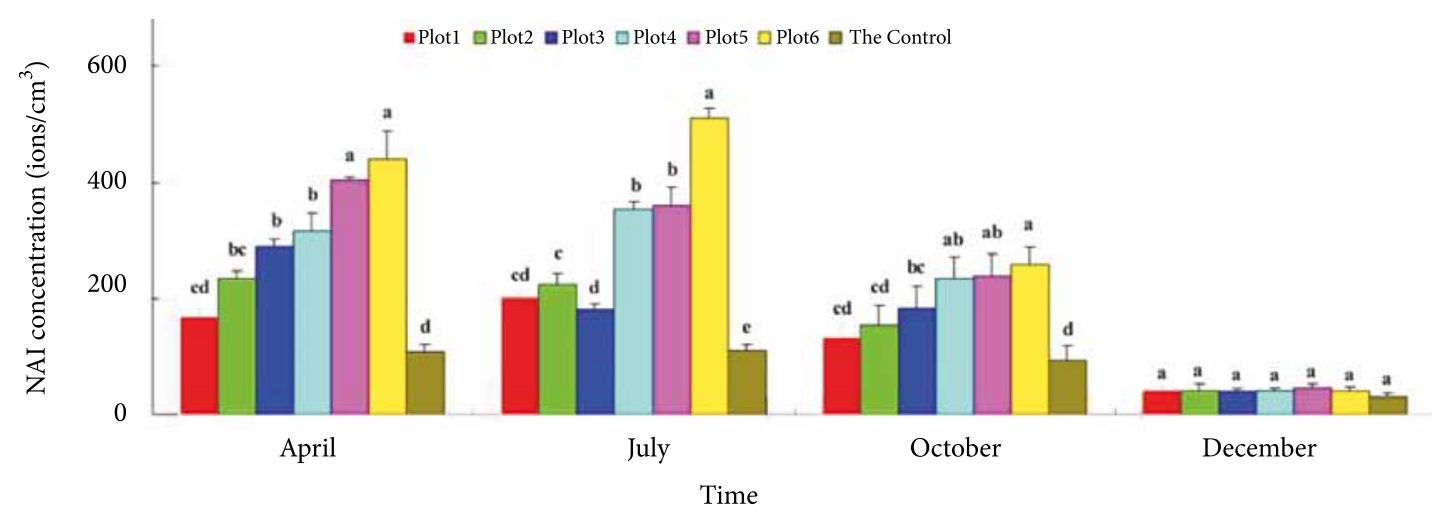

Different letters indicate significant differences among green belts with different widths at 0.05 level.

Fig. 11. The 3-day average of NAI concentration in the green belts

there was no significant difference in the 3-day average NAI concentration among the plots. In July, the NAI concentration benefit was most obvious, and the maximum NAI concentration was 510 ions $/ \mathrm{cm}^{3}$ in plot 6 .

For all seasons, the change in the 3-day average NAI concentration grew with the width of the green belt. The width of plots 1-3 had little effect on the increase in the NAI concentration, there was a clear effect in plot 4 , and there was a conspicuous, stable effect in plots 5 and 6 .

According to the linear correlation analysis of the average NAI concentration (Fig. 12) and the 3-day average NAI concentration (Fig. 11), the NAI benefits in plot 5 were similar to those in plot 6 and higher than those in plot 4 , suggesting that the optimal width reference value of an urban green belt for the effect on the increase in NAI was that of plot 5 .

\subsubsection{Comparison of the air ion assessment coefficient and the air-cleanliness class}

The air ion assessment coefficient and the air-cleanliness class were calculated from the data using the formula of CI (air ion assessment coefficient). A higher CI means

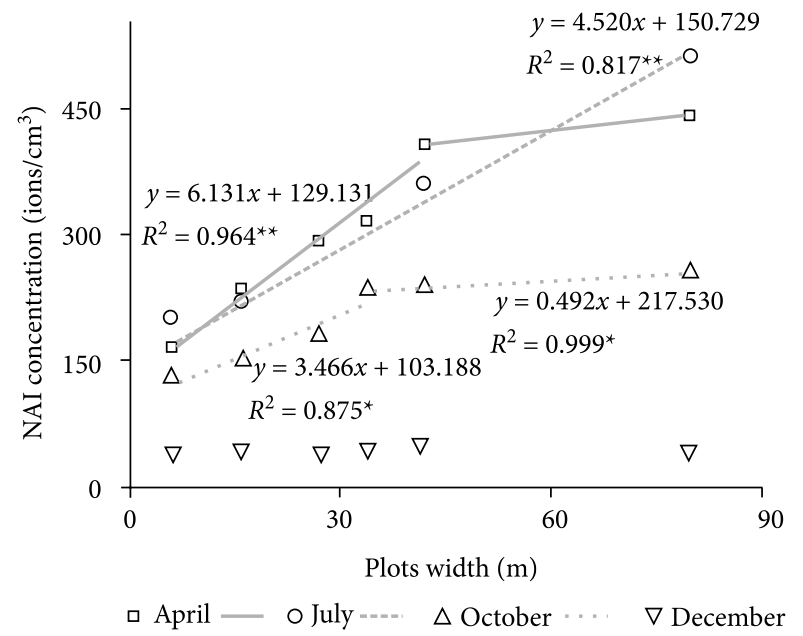

Fig. 12. Linear correlation analysis of average NAI concentrations in green belts better air quality. When $\mathrm{CI}>1.00$, the air quality was the best, A degree; when CI was $1.00-0.70$, air quality was clean, B degree; when CI was 0.69-0.50, average quality, C degree; when CI was 0.49-0.30, below average quality, $\mathrm{D}$ degree; when $\mathrm{CI} \leq 0.29$, polluted, $\mathrm{E}$ degree. In plot 1 ): CI was 0.29-0.19, lightly polluted, E1 degree; 2): CI was $0.18-0.10$, polluted, E2 degree; 3 ): $\mathrm{CI}<0.09$, severely polluted, E3 degree.

As seen in Table 4, the order of the air ion assessment coefficient (CI) and the air-cleanliness class was July > April $>$ October $>$ December. In July, plot 6 had a higher air-cleanliness class, whereas there was no obvious difference between plots 4 and 5 , which were higher than plots 1-3; plots 1-3 had a lower CI and barely achieved the B degree. In April, air cleanliness was lower and the average air-cleanliness class was of D degree in plots $4-6$, whereas the class of plot 3 was higher than plots 1 and 2 and the average air-cleanliness class was E1 degree. The air-cleanliness class of plot 1 was of E2 degree. In October, plot 6 had the highest air ion assessment coefficient, and the air-cleanliness class was of D degree; plots 4 and 5 were significantly higher than plots $1-3$, and the air-cleanliness class was of E1 degree. In December, all plots were of E3 degree.

\subsection{Effect of different widths of green belts on inhibiting bacteria}

\subsubsection{Change in bacteria rates over 3 days}

The 3-day BR for plots and the control was analysed.

To investigate the air-purification ability of green belts, their effect on decreasing the BR was analysed by atmospheric biological monitoring. Over 3 days, the change in atmosphere BRs showed a similar trend in the six plots. As observed in Figure 13, in July and October, the changes in the BRs in plots 4-6 were stable, and the effect on inhibiting bacteria did not vary with width. In April, the BRs of plots 5 and 6 decreased, whereas in December, there was no obvious variation in BR. 
Table 4. Air ion assessment coefficient and air cleanliness class of green belts during seasons

\begin{tabular}{|c|c|c|c|c|c|c|c|c|c|c|c|c|c|c|c|}
\hline \multirow{2}{*}{$\begin{array}{l}\text { Experi- } \\
\text { mental } \\
\text { period }\end{array}$} & \multirow{2}{*}{$\begin{array}{c}\text { Time } \\
\text { intervals }\end{array}$} & \multicolumn{2}{|c|}{ Plot 1} & \multicolumn{2}{|c|}{ Plot 2} & \multicolumn{2}{|c|}{ Plot 3} & \multicolumn{2}{|c|}{ Plot 4} & \multicolumn{2}{|c|}{ Plot 5} & \multicolumn{2}{|c|}{ Plot 6} & \multicolumn{2}{|c|}{ The Control } \\
\hline & & $\mathrm{CI}$ & $\begin{array}{c}\text { Deg- } \\
\text { ree }\end{array}$ & $\mathrm{CI}$ & $\begin{array}{c}\text { Deg- } \\
\text { ree }\end{array}$ & $\mathrm{CI}$ & $\begin{array}{c}\text { Deg- } \\
\text { ree }\end{array}$ & CI & & $\mathrm{CI}$ & $\begin{array}{c}\text { Deg- } \\
\text { ree }\end{array}$ & $\mathrm{CI}$ & $\begin{array}{c}\text { Deg- } \\
\text { ree }\end{array}$ & $\mathrm{CI}$ & $\begin{array}{l}\text { Deg- } \\
\text { ree }\end{array}$ \\
\hline \multirow{6}{*}{ April } & 8: 00-10: 00 & 0.07 & E3 & 0.24 & E1 & 0.46 & $\mathrm{D}$ & 0.27 & E1 & 0.53 & $\mathrm{C}$ & 0.55 & $\mathrm{C}$ & 0.04 & E3 \\
\hline & 10: 00-12: 00 & 0.25 & E1 & 0.19 & E1 & 0.26 & E1 & 0.30 & $\mathrm{D}$ & 0.31 & $\mathrm{D}$ & 0.46 & $\mathrm{D}$ & 0.04 & E3 \\
\hline & 12: 00-14: 00 & 0.13 & E2 & 0.12 & $\mathrm{E} 2$ & 0.18 & $\mathrm{E} 2$ & 0.29 & $\mathrm{E} 1$ & 0.25 & E1 & 0.20 & E1 & 0.11 & $\mathrm{E} 2$ \\
\hline & 14: 00-16: 00 & 0.11 & E2 & 0.16 & E2 & 0.24 & E1 & 0.30 & $\mathrm{D}$ & 0.25 & E1 & 0.23 & E1 & 0.07 & E3 \\
\hline & 16: 00-18: 00 & 0.11 & E2 & 0.21 & E1 & 0.33 & $\mathrm{D}$ & 0.58 & $\mathrm{C}$ & 0.37 & $\mathrm{D}$ & 0.25 & E1 & 0.16 & E2 \\
\hline & Average & 0.13 & E2 & 0.18 & E2 & 0.29 & E1 & 0.35 & $\mathrm{D}$ & 0.34 & $\mathrm{D}$ & 0.34 & $\mathrm{D}$ & 0.09 & E3 \\
\hline \multirow{6}{*}{ July } & 8: 00-10: 00 & 0.62 & $\mathrm{C}$ & 0.30 & $\mathrm{D}$ & 0.13 & $\mathrm{E} 2$ & 2.08 & $\mathrm{~A}$ & 2.76 & $\mathrm{~A}$ & 3.21 & $\mathrm{~A}$ & 0.04 & E3 \\
\hline & 10: $00-12: 00$ & 0.39 & $\mathrm{D}$ & 0.86 & $\mathrm{~B}$ & 0.84 & $\mathrm{~B}$ & 1.00 & $\mathrm{~A}$ & 0.62 & $\mathrm{C}$ & 1.64 & $\mathrm{~A}$ & 0.09 & E3 \\
\hline & 12: $00-14: 00$ & 0.42 & $\mathrm{D}$ & 0.23 & E1 & 0.19 & E1 & 0.60 & $\mathrm{C}$ & 0.32 & $\mathrm{D}$ & 0.59 & $\mathrm{C}$ & 0.05 & E3 \\
\hline & 14: $00-16: 00$ & 0.45 & $\mathrm{D}$ & 0.59 & $\mathrm{C}$ & 0.18 & E2 & 0.65 & $\mathrm{C}$ & 0.80 & $\mathrm{~B}$ & 0.72 & $\mathrm{~B}$ & 0.06 & E3 \\
\hline & 16: 00-18: 00 & 0.19 & E1 & 1.51 & $\mathrm{~A}$ & 0.58 & $\mathrm{C}$ & 1.08 & $\mathrm{~A}$ & 0.86 & $\mathrm{~B}$ & 3.56 & $\mathrm{~A}$ & 0.37 & $\mathrm{D}$ \\
\hline & Average & 0.41 & $\mathrm{D}$ & 0.70 & $\mathrm{~B}$ & 0.38 & $\mathrm{D}$ & 1.08 & $\mathrm{~A}$ & 1.07 & $\mathrm{~A}$ & 1.94 & $\mathrm{~A}$ & 0.12 & E2 \\
\hline \multirow{6}{*}{ October } & 8: 00-10: 00 & 0.12 & $\mathrm{E} 2$ & 0.04 & E3 & 0.11 & E2 & 0.09 & E3 & 0.35 & $\mathrm{D}$ & 0.31 & $\mathrm{D}$ & 0.27 & E1 \\
\hline & 10: $00-12: 00$ & 0.18 & E2 & 0.25 & E1 & 0.18 & E2 & 0.35 & $\mathrm{D}$ & 0.18 & E1 & 0.78 & $\mathrm{~B}$ & 0.09 & E3 \\
\hline & 12: $00-14: 00$ & 0.05 & E3 & 0.05 & E3 & 0.33 & $\mathrm{D}$ & 0.20 & E1 & 0.32 & $\mathrm{D}$ & 0.22 & E1 & 0.44 & $\mathrm{D}$ \\
\hline & 14: 00-16: 00 & 0.02 & E3 & 0.03 & E3 & 0.21 & E1 & 0.42 & $\mathrm{D}$ & 0.30 & $\mathrm{D}$ & 0.18 & E2 & 0.10 & E2 \\
\hline & 16: 00-18: 00 & 0.11 & E2 & 0.16 & E2 & 0.18 & E2 & 0.28 & E1 & 0.14 & $\mathrm{E} 2$ & 0.20 & E1 & 0.03 & E3 \\
\hline & Average & 0.10 & E2 & 0.16 & $\mathrm{E} 2$ & 0.17 & E2 & 0.29 & E1 & 0.24 & E1 & 0.38 & $\mathrm{D}$ & 0.10 & $\mathrm{E} 2$ \\
\hline \multirow{6}{*}{$\begin{array}{l}\text { Decem- } \\
\text { ber }\end{array}$} & 8: 00-10: 00 & 0.06 & E3 & 0.05 & E3 & 0.02 & E3 & 0.03 & E3 & 0.02 & E3 & 0.02 & E3 & 0.02 & E3 \\
\hline & 10: $00-12: 00$ & 0.09 & E3 & 0.08 & E3 & 0.04 & E3 & 0.07 & E3 & 0.07 & E3 & 0.06 & E3 & 0.04 & E3 \\
\hline & 12: $00-14: 00$ & 0.07 & E3 & 0.09 & E3 & 0.03 & E3 & 0.07 & E3 & 0.03 & E3 & 0.06 & E3 & 0.02 & E3 \\
\hline & 14: 00-16: 00 & 0.13 & $\mathrm{E} 2$ & 0.04 & E3 & 0.06 & E3 & 0.04 & E3 & 0.05 & E3 & 0.12 & $\mathrm{E} 2$ & 0.01 & E3 \\
\hline & 16: 00-18: 00 & 0.01 & E3 & 0.03 & E3 & 0.03 & E3 & 0.05 & E3 & 0.02 & E3 & 0.04 & E3 & 0.14 & $\mathrm{E} 2$ \\
\hline & Average & 0.07 & E3 & 0.06 & E3 & 0.03 & E3 & 0.05 & E3 & 0.04 & E3 & 0.06 & E3 & 0.05 & E3 \\
\hline
\end{tabular}

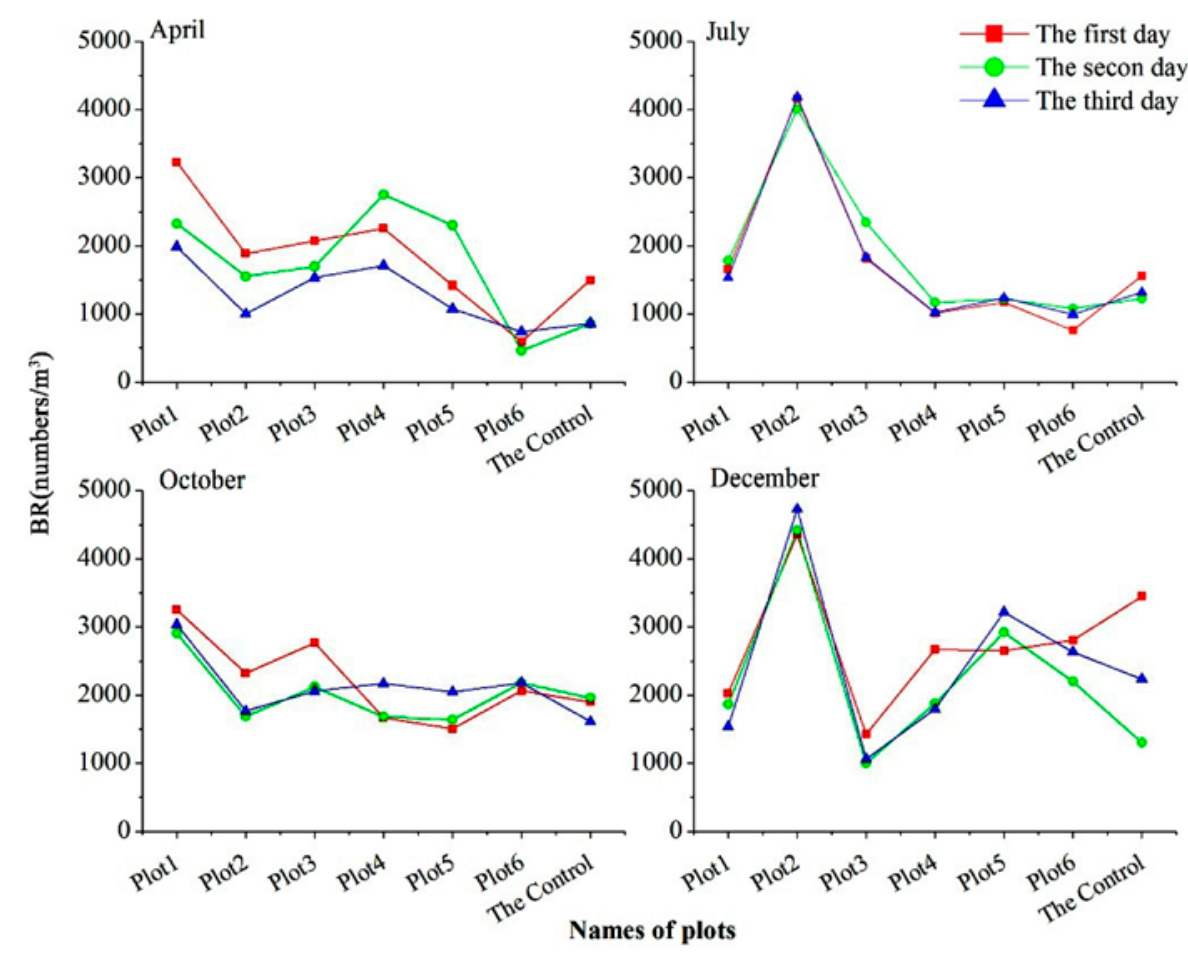

Fig. 13. Air BR changes of green belts over 3 days 


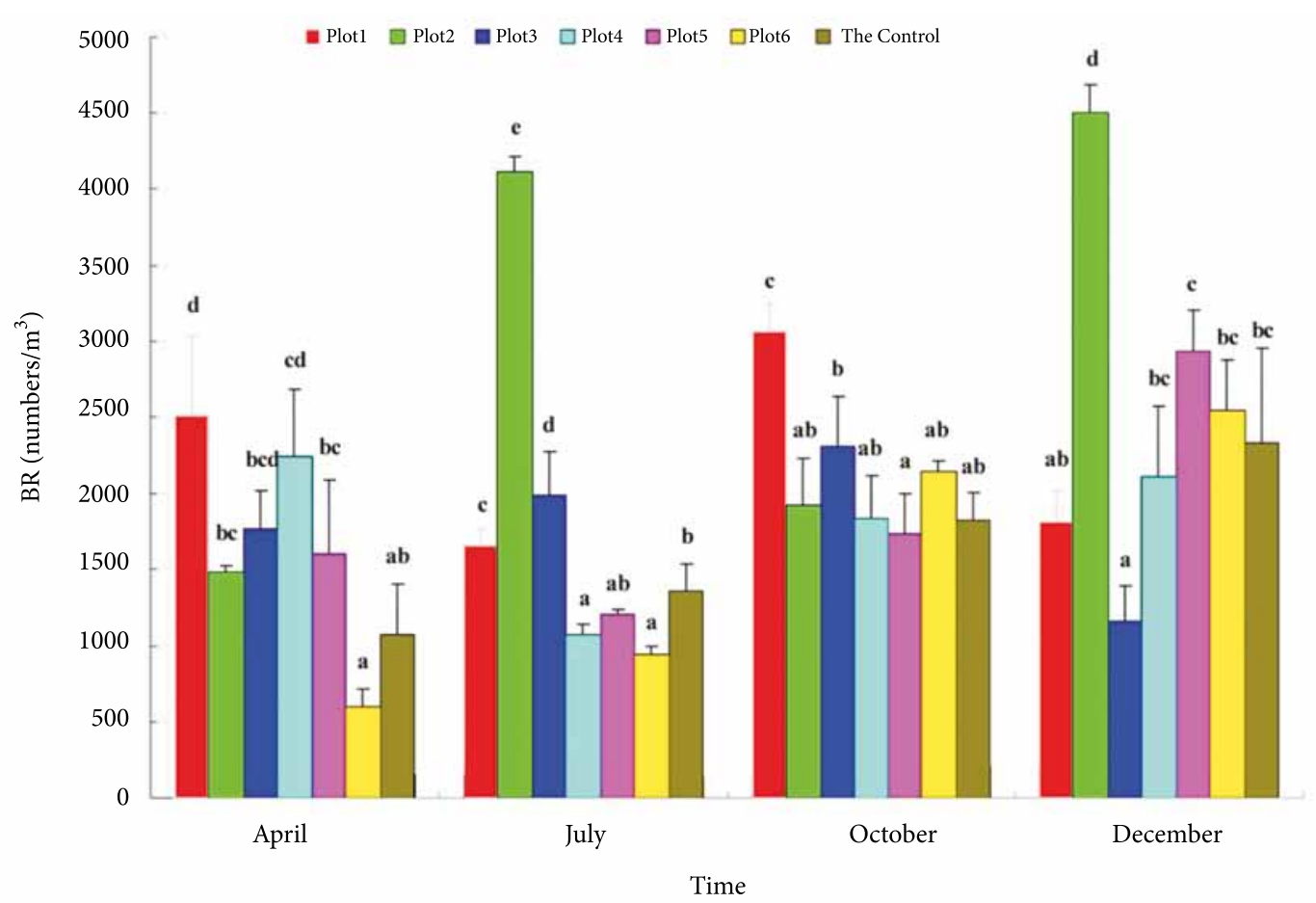

Different letters indicate significant differences among green belts with different widths at 0.05 level.

Fig. 14. The 3-day average BR in the green belts

\subsubsection{Change in the average bacteria rate over 3 days}

The 3-day average BR was analysed for each plot and the control.

The 3-day average BRs for each season (Fig. 14) showed that the BRs in the atmosphere were higher in October and December than in April and July. Based on Duncan's post hoc tests $(P<0.05)$ and using the data from July as an example, there was no significant difference in the 3-day average BR among plots 4-6, but there was a significant difference between the wider plots and plots 1-3. According to the observations in April, July, October and December, the effect of inhibiting bacteria steadily increased and was regular until the width of green belts reached a certain value.

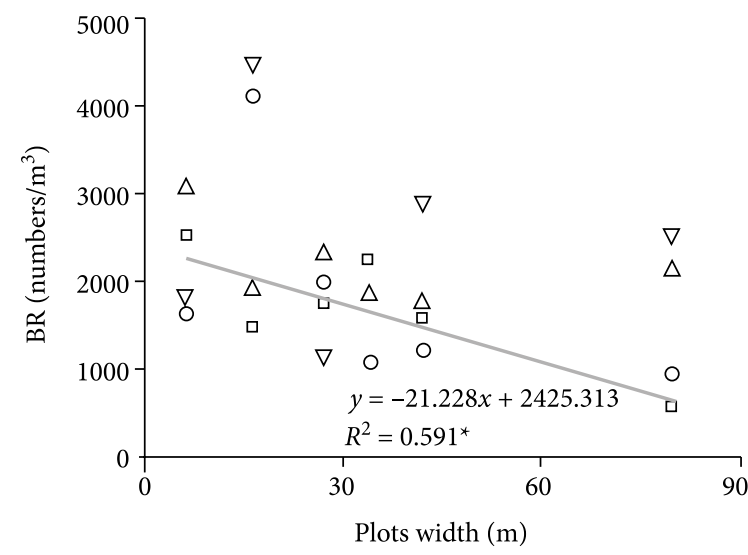

$\square$ April — O July $\Delta$ October $\nabla$ December

Fig. 15. Linear correlation analysis of average BR in green belts
As observed from the curve in Figures 15, there was a significant linear correlation between the BR and the width of plots $(P<0.05)$ in April and no significant linear correlation in July, October and December.

\section{Discussion}

\subsection{Changes in the air temperature and relative humidity}

Previous studies have found that decreases in temperature and increases in humidity caused by urban green space differ according to the vegetation quantity and forest type (Cohen et al. 2012; Hamada, Ohta 2010; Onishi et al. 2010). Recent research has also found that the environmental temperature may be reduced by area, geometry, location and proportion of built-up near the green space (Chang et al. 2007; Cohen et al. 2012; Cao et al. 2010; Sun, Chen 2012). In accordance with these results, the width of urban green belts was also found to significantly influence local $\mathrm{T}$ and $\mathrm{RH}$ in Beijing. These results reflected some physical properties of the thermal transmission among green belts.

The $\mathrm{T}$ benefit was produced by the crown leaves reducing direct solar insolation as well as by cooling from plant transpiration and the leaves blocking the reflected heat from the ground and adjacent objects to reduce long-wave surface radiation (Georgi, Dimitriou 2010; Oliveira et al. 2011; Federer 1976; Berry et al. 2013). The belts changed the radiation conditions at the surface and near the surface for atmospheric radiation, which led 
to the temperature difference between the belts and the bare space. The solar radiation intensity may decrease by more than $80 \%$ as a result of crown shadowing (Tang et al. 2009), and the belts could consume $60-75 \%$ and even $90 \%$ of the energy from solar radiation by plant transpiration, decreasing the air temperature (Profous et al. 1988). The widths of the green belts significantly affected the decreases in air temperature. To isolate the effect of the width on air temperature from data recorded in the six plots, the internal and external environmental conditions were held constant between plots. In every plot, the canopy was similar; thus, the shading of solar irradiation was essentially the same. The leaf area was different in each plot for the varied widths of the green belt, which meant that the wider green belts had stronger transpiration effects and a greater effect on temperature. In contrast, the narrower plots had lower decreases in T. Plot 1 was narrowest and had the least vegetation; thus, the green belt effect was greatly reduced by the surrounding long-wave surface radiation. Hence, it had less of a $\mathrm{T}$ impact on its internal environment. In contrast, plots 5 and 6 were wider and had more vegetation in which transpiration was greater; thus, the internal environment was relatively stable.

There was a very significant negative correlation between $\mathrm{RH}$ and solar radiation, surface radiation and air temperature (Tang et al. 2009). Narrower plots led to greater variation in the $\mathrm{RH}$ of the green belts because of air convection by cold and hot air transmission because of surrounding long-wave surface radiation. Moreover, it was evident that the $\mathrm{RH}$ increased with the width of the plots as a result of water evaporation over the wider area. The wider green belts had relatively quiet air movement, which prevented moisture diffusion from plant and soil transpiration; thus, the water vapour content increased in the local air. In addition, the saturation vapour pressure was lower because of decreased temperature, increasing the relative humidity of the air. Thus, plots $4-6$ were superior to plots $1-3$ at increasing the humidity.

\subsection{Changes in the negative air ions concentration}

The effect of the green belts on the air-cleanliness class varied by width. Narrower green belts had less vegetation, which produced fewer anions, and they had greater air convection by cold and hot air transmission from surrounding long-wave surface radiation, which further reduced the amount of anions. The green belt plots had a significant edge feature, and the NAI concentration at the edge of the green belt was easily affected by the surrounding environment. Therefore, the narrower plots were also largely affected by automobile exhaust and traffic dust, and the pollutants promoted anion collisions and charged neutralization (Krueger 1985; Retalis, Nastos 2009), which led to the unstable NAI concentrations. The wider plots (plots 4-6) were less affected internally by the surrounding environment; hence, the changes in the NAI concentration were stable, and the maximum NAI concentration was constant across time intervals. In contrast, the NAI concentration was significantly positive correlated with the leaf area because of the leaf tips having a photoelectric effect during photosynthesis in the green belts, which are able to promote electrolysis and produce large quantities of NAI (Liu et al. 2011; Tikhonov et al. 2004); in addition, aromatic substances released by forests, such as phytoncide, can also promote air ionization and increase NAI concentrations; the wider plots had a larger leaf area. These plots had more photosynthesis and more oxygen, providing the physical conditions necessary for NAI production (Wang, Li 2009). In addition, there was more transpiration in wider plots. The water vapour could first form charged ions, and the oxygen and water molecules had a better electrophilicity than nitrogen or other gases (Krueger 1962; Wu, Lee 2004), making it easier to form NAI. Therefore, all the analyses indicated that the wider green belts had a higher NAI concentration.

The NAI concentrations varied by seasons. From April to July, the air temperature and precipitation increased gradually, enhancing plant photosynthesis and increasing the absorption and purification of pollutants, which was the main reason for the increase in NAI in July. The change in plot 6 was the most obvious because of its greater width. In October, the temperature was lower, and there was a higher frequency of calm conditions when the atmospheric structure was stable. Temperature inversions appeared easily; therefore, the pollutants were not easily diffused, which led to a gradual decrease in NAI. In December, the deciduous plants were dormant, reducing photosynthesis and the effect of air purification, thus lowering the NAI concentration. There was a similar trend in plots 1-6. Previous studies have found that the NAI differed greatly during the four seasons, the highest and the lowest NAI concentrations occurred in the summer and winter, respectively (Wu et al. 2011; Liang et al. 2014).

Many studies have indicated that the daily changes in NAI are not consistent across seasons, regions, and weather conditions because the variation in the NAI concentration is affected by meteorological conditions such as temperature, humidity, wind direction, wind speed, solar radiation intensity, and atmospheric pressure (Wang, Li 2009; Singh et al. 2009; Vana et al. 2008). The most important meteorological indexes, air temperature and humidity (Wu et al. 2011; Liang et al. 2014), were analysed in this study. The results indicated that the NAI changes were affected by air temperature and humidity in April and July, and there was a significantly negative correlation between NAI concentration and air temperature and a positive correlation between NAI concentration and humidity $(P<0.05)$. During the time intervals, as 
the temperature increased, pollutants diffused and large amounts of NAIs were absorbed; thus, the NAI concentration was reduced. In contrast, as the humidity increased, the pollutants were absorbed by water vapour, increasing the NAI concentration. In October, the NAI concentration was not significantly correlated with air temperature or humidity during daily time intervals. Liu reported that the NAI concentration of plants was " $U$ " or "V" correlated with the solar radiation intensity in the interior of green spaces during daily time intervals (Liu et al. 2011). Therefore, in October, plant photosynthesis was weaker, and during five time intervals, the temperature rose and the humidity fell as the solar radiation increased, reducing the NAI concentration. Moreover, the photoelectric reaction of the plants increased with the increase in the solar radiation intensity, causing a maximum NAI concentration at 12:00-14:00 in October.

Overall, the NAI varied across different seasons. In April and July, temperature and humidity were the main indexes affecting the NAI of the green belts; in October, the NAI was affected by temperature and humidity at 8:00-12:00, and it was significantly affected by the photoelectric reaction of plants at 12:00-14:00. For the above reasons, the changes in the NAI were affected by some indexes. In this study, wider plots (plots 4-6) caused the NAI to be more stable than in the narrower plots, which were easily affected by the above indexes. Therefore, when the plot attained a certain value, the width was a dominant factor. In this study, the consistent external environment and sunny, windless weather conditions were set in all plots; thus, the wind speed, atmospheric pressure, and population/vehicle flow are not discussed separately.

\subsection{Changes in the bacteria rate}

The effect of green belts on inhibiting bacteria was influenced by several factors. Atmospheric BRs were decreased by plant leaves through adsorption, filtration, and the secretion of antibacterial compounds (Zhang et al. 1997). The dust-retention functions of tree leaves play an important role in decreasing BRs. Nowak (Nowak 1994) found that the dust retained on the tree could be adsorbed at rates of $82-86 \%$ for broadleaved trees and $27-52 \%$ for conifers. The BRs were also affected by the traffic on either side of the belts. Traffic caused a significantly greater amount of dust to be retained on the leaf surface, and this hindered the plants' ability to produce antibacterial substances. Furthermore, under certain conditions of temperature and humidity, bacteria propagated more easily (Mesut, Bayram 2010). In the summer, the $\mathrm{T}$ of the green space was lower than that of the controls, whereas the $\mathrm{RH}$ was higher. If a green belt had poor airflow, it would be easier for bacteria to propagate. Therefore, under certain environmental conditions, the dust retained in wider green belts could be greater than that of narrower belts, but this study found that beyond a certain threshold, wider belt with higher humidity had a lower BR, whereas the plants had a stronger effect on the inhibiting bacteria. Therefore, the atmospheric BRs were higher. Further research may be needed to analyze the role of additional variables (such as species and leaf surface roughness).

In this study, the ordering of the BR was December $>$ October $>$ July $>$ April. Compared with April, plant photosynthesis is stronger in July. There is more bactericidal capacity, but the air relative humidity is also higher; thus, it is easier for the bacteria to breed, leading to a higher BR in July than in April. In April, the plants were at a vigorous growth stage and the bacteriostatic ability was strong, which reduced BR compared with other seasons. In December, the plants were deciduous and dormant; thus, the bacteriostatic ability became weaker and the bacteria rate was higher.

The bacteriostatic ability of the six plots varied by seasons. In April, there was a higher BR in plots 1-5 than in the control because the air temperature and humidity were higher in the mornings, which allowed the bacteria to breed. In plot 1 , the bacteria rate was higher. Because of its narrower width, plot 1 was more affected by the dust from traffic and pollen from the flowering "Prunus trilo$b a$ ", increasing the BR. As the width gradually increased, the bacteria rates in plots 3-4 increased, showing that the BR was mainly influenced by the temperature of internal plots. There was a significant positive correlation between the $\mathrm{BR}$ and air temperature $(P<0.05)$ in the mornings in April. However, the BR was lower in plots 5-6, which shows that the width plays a major role. Compared with the narrower plots, the wider plots were less affected by traffic and by dust deposited onto the leaves of the plants or the ground, reducing the bacterial load and causing a decrease in the bacteria rates in the plots. In July, the narrower plots 1-3 were affected by the surrounding air flow and its suspended dust and other particles, resulting in increased microbial settlement. Thus, there was no obvious effect of inhibition of bacteria in plots 1-3. Plot 2 was dominated by "Lonicera maackii", which has rough leaves. The amount of dust trapped was higher than for other species, and the bacteria rates were higher. The wider plots 4-6 had lower BRs, and the changes in the BRs of plots 4-6 were stable; the effect on inhibiting bacteria did not increase with increasing width. In October, all of the plots and the control had a similar BR, and the BR was not significantly correlated with air temperature or humidity $(P<0.05)$. In the mornings in the autumn, the atmospheric structure was stable and temperature inversions were frequent; thus, pollutants were not easily diffused. In addition, solar radiation and plant photosynthesis were weaker, which led to a peak in the microbe concentration. In December, the regular variation of the BRs was not obvious. The plants had a lower bactericidal capability 
because they were dormant and without leaves. In plots 4-6, there were higher BRs, and the BR was significantly positively correlated with air temperature $(P<0.05)$. In plot 2, the BR was higher, perhaps due to the dust that had accumulated on the "Lonicera maackii" returning to the air. Further research and the examination of variables such as solar radiation, wind, and atmospheric pressure may be needed to account for the unexplained variation.

\subsection{Weather factors affecting the negative air ions concentration and bacteria rate}

The NAI concentration and BR were affected by seasonal weather factors. In this study, from the relationship between $\mathrm{T}$ and $\mathrm{RH}$ and between the NAI concentration and BRs at 9:00-9:05 (Fig. 16), the correlation between the NAI concentration and the T and RH was affected by the season. There was a significant negative correlation between the NAI concentration and T and a positive correlation between the NAI concentration and the RH $(P<$ 0.05) in April, July and October; the NAI concentration increased as the width of green belts increased for a higher RH. There was no significant correlation between the NAI concentration and T and RH $(P>0.05)$ in December. There was a significant positive correlation between the BRs and the $\mathrm{T}$ and no significant correlation to $\mathrm{RH}(P<$ 0.05) in April and December. There was no significant correlation between the BRs and the T and $\mathrm{RH}(P>0.05)$ in July and October.

As the effect of green belts could be influenced by the distance in reference to a city centre, it is important to analyse the correlation between green belt positions and the environmental conditions including air T, RH, NAI and BR. Sun et al. (2012) investigated the urban cooling island (UCI) intensity of 187 water bodies outside the Fourth Ring Road and 10 water bodies inside the Fourth Ring Road. The results indicated that the UCI intensity was negatively correlated with location in reference to the defined city centre (Sun et al. 2012). However, the results reported by Li et al. (2004) showed that no significant correlation existed between the underlying surface temperature and the sample point area (inside the Fourth Ring Road) (Li et al. 2004). These results may indicate that temperature has no correlation with location inside the Fourth Ring Road in Beijing. However, few results were reported about the green belt position and other environmental conditions. In this research, different correlations were found between air $\mathrm{T}$ and other conditions including $\mathrm{RH}$, NAI and BR on six widths of green belts inside the Fourth Ring Road of Beijing. Thus, further studies are needed to uncover the correlation between green belt positions and environmental conditions such as RH, NAI and BR.

\section{Conclusions}

Green belts, distributed heterogeneously in urban areas, have significant effects on urban ecological attributes and healthy dwelling environments. Meanwhile, the effective width of urban green belts for better ecological effectiveness is an issue of great concern to many designers and builders, especially in commercial areas and densely populated urban areas. In the present study, an obvious effect of the green belt was observed on the increase of $\mathrm{RH}$ and NAI, the decrease in air $\mathrm{T}$ and the inhibition of BR, especially in April and July. Compared with the bare and hard ground, the air $\mathrm{T}$ of green belts declined by $3.5-$ $10.7 \%$ in July; the RH and NAI increased by $9.5-28.3 \%$ and $84-364 \%$, respectively; and the effect of green belts

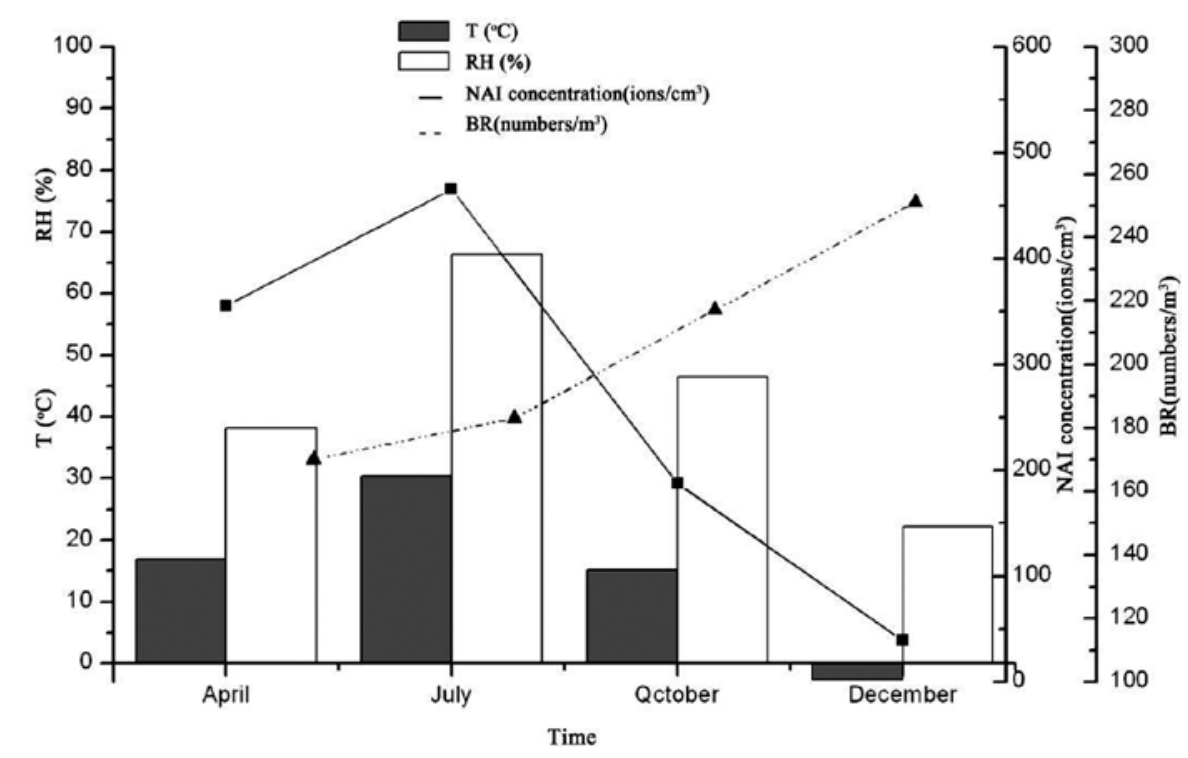

Fig. 16. Correlation between T, RH and the NAI concentration, BR at 9:00-9:05 
on BR inhibition was not significant. These results indicated that the width of the green belt played a vital role on the environmental indicators such as air T, RH, NAI etc. As the width of the green belt increased, the effect on air T, RH and NAI was enhanced. However, the effects were stable when the width of green belt was over $42 \mathrm{~m}$, suggesting that the optimal width reference value of an urban green belt for a measureable effect is approximately $42 \mathrm{~m}$. In this case, the green belts will suffice to stabilize their internal space conditions of the ecological environment and contribute largely to the environment.

Effective utilization of the air T-RH and the air quality effects of green belts through appropriate landscape design and planning is becoming increasingly critical given the worsening city environment and continued rapid urbanization. This study provides planners and designers with useful information for achieving optimal landscape design in urban planning projects. Meanwhile, the assessment of urban ecological attributes and the healthy living environment will enable us to understand the urban green belts and their relationship with human beings in a new perspective and further establish their ecological status. In addition, our results will provide new insights into the development of urban green belt construction and the understanding of the sustainable development of urban ecology.

\section{Acknowledgements}

This work was supported by the "National Science Foundation of China" under Grant [31500576]; "National Science Foundation of China" under Grant [30972416].

\section{References}

Berry, R.; Livesley, S. J.; Aye, L. 2013. Tree canopy shade impacts on solar irradiance received by building walls and their surface temperature, Building and Environment 69: 91-100. https://doi.org/10.1016/j.buildenv.2013.07.009

Cao, X.; Onishi, A.; Chen, J.; Imura, H. 2010. Quantifying the cool island intensity of urban parks using ASTER and IKONOS data, Landscape and Urban Planning 96: 224-231. https://doi.org/10.1016/j.landurbplan.2010.03.008

Chang, C. R.; Li, M. H.; Chang, S. D. 2007. A preliminary study on the local cool-island intensity of Taipei city parks, Landscape and Urban Planning 80: 386-395.

https://doi.org/10.1016/j.landurbplan.2006.09.005

Cohen, P.; Potchter, O.; Matzarakis, A. 2012. Daily and seasonal climatic conditions of green urban open spaces in the Mediterranean climate and their impact on human comfort, Build Environment 51: 285-295.

https://doi.org/10.1016/j.buildenv.2011.11.020

Federer, C. A. 1976. Trees modify the urban microclimate, Arboricultural Journal 2: 121-127.

Feyisa, G. L.; Dons, K.; Meilby, H. 2014. Efficiency of parks in mitigating urban heat island effect: an example from Addis Ababa, Landscape and Urban Planning 123: 87-95. https://doi.org/10.1016/j.landurbplan.2013.12.008
Fitzsimons, J.; Pearson, C. J.; Lawson, C.; Hill, M. J. 2012. Evaluation of land-use planning in greenbelts based on intrinsic characteristics and stakeholder values, Landscape and Urban Planning 106: 23-34.

https://doi.org/10.1016/j.landurbplan.2012.01.012

Georgi, J. N.; Dimitriou, D. 2010. The contribution of urban green spaces to the improvement of environment in cities: case study of Chania, Greece, Build Environment 45: 14011414. https://doi.org/10.1016/j.buildenv.2009.12.003

Gunn, S. C. 2007. Green belts: A review of the regions' responses to a changing housing agenda, Journal of Environment Planning and Management 50: 595-616. https://doi.org/10.1080/09640560701475154

Hamada, S.; Ohta, T. 2010. Seasonal variations in the cooling effect of urban green areas on surrounding urban areas, Urban Forestry and Urban Greening 9: 1-24. https://doi.org/10.1016/j.ufug.2009.10.002

Hathway, E. A.; Sharples, S. 2012. The interaction of rivers and urban form in mitigating the Urban Heat Island effect: a UK case study, Building and Environment 58: 14-22. https://doi.org/10.1016/j.buildenv.2012.06.013

Islam, M. N.; Rahman, K. S.; Bahar, M. M.; Habib, M. A.; Ando, K.; Hattori, N. 2012. Pollution attenuation by roadside greenbelt in and around urban areas, Urban Forestry and Urban Greening 11: 460-464. https://doi.org/10.1016/j.ufug.2012.06.004

Ji, P.; Zhu, C. Y.; Li, S. H. 2013. Effects of greenbelt width on air temperature and humidity in urban river corridors, Chinese Journal of Plant Ecology 37(1): 37-44 (in Chinese). https://doi.org/10.3724/SP.J.1258.2013.00004

Krueger, A. P. 1962. Air ions and physiological function, Journal of General Physiology 45: 233-241. https://doi.org/10.1085/jgp.45.4.233

Krueger, A. P. 1985. The biological effects of air ions, International Journal of Biometeorology 3: 205-206. https://doi.org/10.1007/BF02189651

Li, Y. M.; Zhang, J. H.; Gu, R. Z. 2004. Research on the relationship between urban greening and the effect of urban heat island, Journal of Chinese Landscape Architecture 1: 72-75 (in Chinese).

Liang, H.; Chen, X. S.; Yin, J. G.; Da, L. J. 2014. The spatial-temporal pattern and influencing factors of negative air ions in urban forests, Shanghai, China, Journal of Forestry Research 25: 847-856. https://doi.org/10.1007/s11676-014-0475-9

Liu, X.; Wu, L. H.; Zhang, H.; Wang, X. R. 2011. Study on the concentration of negative air ions and the influential factors in different urban plant communities, Journal of Fudan University (Natural Science) 50: 206-212 (in Chinese).

Mackey, C. W.; Lee, X. H.; Smith, R. B. 2012. Remotely sensing the cooling effects of city scale efforts to reduce urban heat island, Build Environment 49: 348-358. https://doi.org/10.1016/j.buildenv.2011.08.004

Maimaitiyiming, M.; Ghulam, A.; Tiyip, T.; Pla, F.; Carmona, P. L.; Halik, Ü.; Sawut, M.; Caetano, M. 2014. Effects of green space spatial pattern on land surface temperature: implications for sustainable urban planning and climate change adaptation, Journal of Photogrammetry Remote Sensing 89: 59-66. https://doi.org/10.1016/j.isprsjprs.2013.12.010

Mesut, D.; Bayram, K. 2010. A preliminary assessment of the water and air quality parameters in and around the Lake Yenicaga coast, Journal of the Black Sea/Mediterranean Environment 16: 167-194. 
Nowak, D. J. 1994. Air pollution removal by Chicago's urban forest USDA forest service gen, Technology Report 186: 62-83.

Oliveira, S.; Andrade, H.; Vaz, T. 2011. The cooling effect of green spaces as a contribution to the mitigation of urban heat: A case study in Lisbon, Build Environment 46: 21862194. https://doi.org/10.1016/j.buildenv.2011.04.034

Onishi, A.; Cao, X.; Ito, T.; Shi, F.; Imura, H. 2010. Evaluating the potential for urban heat-island mitigation by greening parking lots, Urban Forestry and Urban Greening 9: 323-332. https://doi.org/10.1016/j.ufug.2010.06.002

Profous, G. V.; Rowntree, R. A.; Loeb, R. E. 1988. The urban forest landscape of Athens, Greece: aspects of structure, planning and management, Arboricultural Journal 12: 83-107. https://doi.org/10.1080/03071375.1988.9756380

Retalis, A.; Nastos, P. 2009. Study of small ions concentration in the air above Athens, Greece, Atmospheric Research 91: 219-228. https://doi.org/10.1016/j.atmosres.2008.05.011

Rohling, J. 1998. Corridors of green, N C Wild 5: 22-27.

Schiller, A. 1997. Wildlife conservation in urban greenways of the mid-southeastern, United States: Urban Ecosystem 1: 103116. https://doi.org/10.1023/A:1018515309254

Singh, K.; Malik, A.; Singh, M. 2009. Spatial variation in air ion concentrations under different indoor environments, International Journal of BioScience, Psychiatrie and Technology 1: 36-41.

Smith, D. S. 1993. An overview of greenways: their history, ecological context, and specific functions, in D. S. Smith (Ed.). Ecology of greenways. Minneapolis: University of Minnesota Press, 1-21.

Sun, R. H.; Chen, L. D. 2012. How can urban water bodies be designed for climate adaptation?, Landscape and Urban Planning 105: 27-33. https://doi.org/10.1016/j.landurbplan.2011.11.018

Tang, L. Z.; Li, Z. Q.; Yan, C. F.; Sun, C. H.; Xu, X.; Xiang, H. R. 2009. Mitigative effects of different vegetations on heat island effect in Nanjing, Ecology and Environmental Sciences 18: 23-28 (in Chinese).
Tikhonov, V. P.; Tsvetkov, V. D.; Litvinova, E. G. 2004. Generation of negative air ions by plants upon pulsed electrical stimulation applied to soil, Journal of Plant Physiology 51: 414-419. https://doi.org/10.1023/B:RUPP.0000028690.74805.e2

Vana, M.; Ehn, M.; Petaja, T.; Vuollekoski, H.; Aalto, P.; de Leeuw, G.; Ceburnis, D.; O’Dowd, C. D.; Kulmala, M. 2008. Characteristic features of air ions at Mace Head on the west coast of Ireland, Atmospheric Research 90: 278-286. https://doi.org/10.1016/j.atmosres.2008.04.007

Wang, J.; Li, S. H. 2009. Changes in negative air ions concentration under different light intensities and development of a model to relate light intensity to directional change, Journal of Environmental Management 90: 2746-2754. https://doi.org/10.1016/j.jenvman.2009.03.003

Wang, J.; Lin, Y. D. 2006. Role of green land in urban on the reduction of heat island effect, Grassland and Turf 6: 56-59 (in Chinese).

Wu, C. C.; Lee, G. W. M. 2004. Oxidation of volatile organic compounds by negative air ions, Atmospheric Environment 38: 6287-6295. https://doi.org/10.1016/j.atmosenv.2004.08.035

Wu, C. F.; Lai, C. H.; Chu, H. J.; Lin, W. H. 2011. Evaluating and mapping of spatial air ion quality patterns in a residential garden using a geostatistic method, International Journal of Environmental Research and Public Health 8: 2304-2319. https://doi.org/10.3390/ijerph8062304

Wu, W. T.; Zhao, H. Y.; Ren, Y.; Shen, D.; Zhang, Y. 2012. Study on barriers and countermeasures of technological innovation of ecological service function assessment of urban greenbelt, Energy Procedia 16: 115-120. https://doi.org/10.1016/j.egypro.2012.01.021

Zhang, X. X.; Gu, R. Z.; Li, Y. M.; Li, H. 1997. The effect of green space in residential area on the air bacteria rates, Chinese Landscape Architecture 13: 57-58 (in Chinese).

Chunyang ZHU. D Agr, Lecturer of the College of Horticulture and Forest, Huazhong Agricultural University, Wuhan 430070, China. Publications: author/co-author of over 20 scientific papers. Research interests: ecological environment benefit and landscape planning.

Peng JI. D Agr, Associate Professor of the College of agronomy, Heilongjiang Bayi Agricultural University, Daqing 163319, China. Publications: author/co-author of over 10 scientific papers. Research interests: ecological environment benefit.

Shuhua LI. D Agr, Professor of the Department of Landscape Architecture, School of Architecture, Tsinghua University, Beijing 100084, China. Publications: author/co-author of over 50 scientific papers. Research interests: ecological environment benefit. 